\title{
Intermittent Fasting Attenuates Apoptosis, Modulates Autophagy and Preserves Telocytes in Doxorubicin Induced Cardiotoxicity in Albino Rats: A Histological Study
} Article

\author{
Eman Abas Farag and Marwa Mohamed Sabry
}

Histology Department, Faculty of Medicine, Cairo University, Egypt

\begin{abstract}
Background: Doxorubicin (DOX) is an effective anticancer drug, however its use is limited due to severe cardiotoxic effects as ventricular dysfunction, cardiomyopathy and heart failure. Intermittent fasting (IF) has a potential preventive and therapeutic effects against variety of diseases including cardiovascular and neurodegenerative disorders.

Aim of Work: Investigating the effects of DOX on the histological structure of myocardium and evaluating the possible cardioprotective effects of IF on these changes.

Materials and Methods: Forty eight adult male albino rats were divided equally into four groups: control, fasting (16 hours fasting $/ 8$ hours eating), DOX (received $3 \mathrm{mg} / \mathrm{kg}$ every other day for a total of six intraperitoneal injections) and fasting DOX. Body weight, levels of cardiac biomarkers, Malondialdehyde (MDA) and autophagic indicators (LC3II \& p62) were measured. Myocardial specimens were processed for paraffin blocks and stained with H\&E, Mallory's trichrome and immunohistochemical stains for $\mathrm{p} 53$. Moreover, resin blocks were processed for semithin and ultrathin sections examination. Morphometric and statistical studies were performed.

Results: In DOX group, cardiac biomarkers, MDA, LC3II and p62 levels were significantly elevated compared to control group. In addition to, marked histological alterations in myocytes, telocytes and autophagic process. Also, there was significant decrease in cardiomyocytes diameter, significant increase in p53 positive cells and area percent of collagen fibres versus control. On the other hand, IF protected cardiac tissues against the toxic effects of DOX as evidenced by amelioration of histopathological changes and the non significant difference in the levels of cardiac enzymes, MDA, LC3II and p62, cardiomyocytes diameter, p53 positive expressions and area percent of collagen fibres compared to control group.

Conclusion: Doxorubicin administration resulted into deleterious effects on the myocardium. Intermittent fasting had cardioprotective effects against Dox-induced cardiotoxicity via restoration of oxidative state, attenuation of apoptosis, regulation of autophagic process and preservation of telocytes.
\end{abstract}

Received: 09 January 2020, Accepted: 20 January 2020

Key Words: Autophagy, cardiotoxicity, doxorubicin, intermittent fasting, telocytes.

Corresponding Author: Eman Abas Farag, MD, Histology Department, Faculty of Medicine, Cairo University, Cairo, Egypt, Tel.: +20 1140639636, E-mail: emanabas@kasralainy.edu.eg

ISSN: 1110-0559, Vol. 43, No.3

\section{INTRODUCTION}

Doxorubicin (DOX) is one of the highly effective anthracycline antitumor agents used to treat several malignancies such as leukemia, lymphoma, soft tissue sarcoma and breast cancer ${ }^{[1]}$. Unfortunately, DOX clinical use is restricted mainly by its cumulative irreversible cardiotoxicity. Doxorubicin can impair the pumping function of the left ventricle resulting in dilated cardiomyopathy and congestive heart failure with subsequent termination of the treatment and worsening of the patient prognosis ${ }^{[1,2]}$.

To date, the mechanisms of DOX induced cardiotoxicity are not completely clarified. Several factors were supposed to occur simultaneously interacting with each other such as oxidative stress (OS), DNA damage, mitochondrial dysfunction, energy deficiency, calcium disorder, lysosomal destruction, apoptosis and dysregulation of autophagy ${ }^{[3-5]}$.
Macroautophagy, "autophagy" from this time forward, is a lysosome-dependent quality control process to degrade and turnover damaged organelles and misfolded proteins for cellular renewal. So far, the role of autophagy in the maintenance of tissue homeostasis is widely acknowledged but its role during tissue injury and regeneration is still emerging ${ }^{[6]}$.

Baseline autophagy is needed to maintain cardiac structure and function as impaired autophagy has been reported to promote the pathogenesis and progression of several heart diseases like ischemia reperfusion injury, cardiac hypertrophy, cardiac aging, and heart failure ${ }^{[7,8]}$. In addition, previous studies showed that augmentation of autophagy could improve intracellular oxidative injury ${ }^{[9]}$. Recently reported studies have verified that DOX can induce autophagy; however, it causes dysregulation in the autophagic flux and the autophagic process cannot be accomplished ${ }^{[10]}$. Thus, restoration of autophagy could 
be a prospective approach for dealing with DOX induced cardiomyopathy.

Fasting is non pharmacological agent that was shown to stimulate myocardial autophagy ${ }^{[11]}$. It is characterized by complete food deprivation without water, with intervals of normal food intake. According to duration of fasting, it is classified as periodic fasting (successive fasting period for more than 24 hours), alternate day fasting, and intermittent fasting (IF ${ }^{[12]}$. Intermittent fasting includes alternating cycles of feeding and fasting (typically 16 hours (h) fasting with complete deprivation of food not water and $8 \mathrm{~h}$ eating with normal food intake $)^{[13]}$. Popularity of IF was attributed to its potential valuable effects on health ${ }^{[14]}$. Furthermore, IF improved a series of cardiovascular conditions including hypertension $^{[15]}$ and post myocardial infarction damage ${ }^{[16]}$.

Telocytes, distinct interstitial cells found in most organs, are recently suggested to be involved in cardiac homoeostasis and regeneration. Cardiac telocytes are increasingly regarded as key regulators in intercellular signaling with numerous cell types like cardiomyocytes, stem cells, blood capillaries, nerve endings and fibroblasts, thus making considerable influence in cardiac physiology and response to injury ${ }^{[17]}$. Therefore, detection of methods able to enhance telocytes growth and function might be a novel therapeutic or prophylactic approach for numerous acute and chronic heart diseases ${ }^{[18]}$.

So far, Effective therapeutic strategies to cure DOX cardiotoxicity are still not present. Thus, it remains a challenge to find an effective agent which might be combined with DOX preventing or reducing its cardiotoxicity and at the same time able to maintain its efficacy and safety in tumor treatments ${ }^{[19]}$.

Therefore, this study aimed to detect the effects of DOX on the histological structure of myocardium in adult albino rats and evaluating the possible cardioprotective effects of IF on these changes and on autophagy and telocytes as well.

\section{MATERIALS AND METHODS}

\section{Drug}

Doxorubicin (DOX): It was purchased from EBEWE Pharma (Ges.m.b.H., A-4866 Unterach, Austria) as $5 \mathrm{ml}$ vials contained $10 \mathrm{mg}$ doxorubicin $\mathrm{HCl}$ in $0.9 \%$ sodium chloride.

\section{Animals \\ Forty eight adult male albino rats of average weight $200 \mathrm{~g}$ were treated according to Cairo University Animal Use Committee guidelines. They were housed in the Animal house of Kasr Al-Aini Faculty of Medicine, Cairo University. Rats were housed in polypropylene cages with good aerated wire mesh covers at controlled temperature $24 \pm 1{ }^{\circ} \mathrm{C}$ as well as normal light/dark cycle (12 h light/12 h dark).}

\section{III) Experimental Design}

The first day of experiment was assigned as day 1. All rats were sacrificed at day 28 . Rats were divided equally into 4 groups:

Group I (Control group): supplied, all over 24 hours of the day, with standard rat chow with free access to water and food. They were equally divided into two subgroups:

Subgroup Ia: left without further treatment (served as control for fasting subgroup IIa).

Subgroup Ib: received intraperitoneal (IP) injection of $0.3 \mathrm{ml}$ saline every other day (days 17, 19, 21, 23, 25 and 27). They served as control for fasting subgroup IIb and DOX group.

Group II (Fasting group): rats underwent IF protocol in which they were deprived of food only not water for $16 \mathrm{~h}$ daily staring from $6 \mathrm{pm}$ to $10 \mathrm{am}$. During non fasting $8 \mathrm{~h}$, rats had ad libitum access to food and water without caloric restriction ${ }^{[13,20]}$. They were equally divided into 2 subgroups

Subgroup IIa: left without further treatment.

Subgroup IIb: received IP injection of $0.3 \mathrm{ml}$ saline every other day (days 17, 19, 21, 23, 25 and 27).They served as control for group IV (fasting DOX group).

Group III (DOX group): supplied, all over 24 hours of the day, with standard rat chow with free access to water and food similar to control group. Rats received ( $3 \mathrm{mg} / \mathrm{kg})$ IP injection of doxorubicin (i.e each rat received $0.3 \mathrm{ml}$ saline contained $0.6 \mathrm{mg}$ DOX) every other day from day 17 (days 17, 19, 21, 23, 25 and 27) for a total of 6 injections (cumulative dose $18 \mathrm{mg} / \mathrm{kg}$ ) then they were sacrificed one day after the last injection (at day 28) ${ }^{[21]}$.

Group IV (Fasting DOX group): underwent IF protocol as group II and were received simultaneous DOX injections similar to group III.

\section{IV) Experimental Procedure}

1. Body weight for all animal was recorded at days 1,17 and 28 .

2. Biochemical investigations:

- Just before scarification time, blood samples from tail veins of all rats were collected in heparinized capillary tubes and serum Troponin $\mathrm{T}$, lactate dehydrogenase (LDH) and creatine phosphokinase (CPK) enzymes were measured to determine myocardial injury. Rats were sacrificed after being anaesthetized with IP injection of ketamine (90 $\mathrm{mg} / \mathrm{kg}) / \mathrm{xylazine}(15 \mathrm{mg} / \mathrm{kg})^{[22]}$ and the hearts of all rats were dissected to obtain the left ventricular muscles. Cardiac homogenates were prepared to measure expression level of:

- Malondialdehyde (MDA): indicator of lipid peroxidation and $\operatorname{OS}^{[23]}$

- $\quad$ LC3II (ab48394, abcam, Cambridge,UK) and p62 (ab109012, abcam, Cambridge,UK): indicators of autophagy by Western blot analysis ${ }^{[2]}$. 
LC3II (microtubule-associated protein 2 light chain 3) is considered the only reliable protein marker associated with autophagosomes formation ${ }^{[25]}$.

p62: regulates the formation of protein aggregates and is removed by autophagy during the digestion steps. Thus, its accumulation indicates failure to complete autophagic process $^{[26]}$.

All measurements were conducted at the Unit of Biochemistry and Molecular Biology at Biochemistry Department, Faculty of Medicine, Cairo University.

\section{Histological Studies}

- For light microscopic studies, left ventricle specimens were fixed in $10 \%$ formol saline and processed to paraffin blocks. Sections were cut at six micro meters thickness and stained with:

- Hematoxylin and Eosin (H\&E) $)^{[27]}$

- Mallory's trichrome stain to detect collagen fibres $^{[27]}$

- Immunohistochemical staining for p53 as a marker for apoptosis. It is a rabbit polyclonal antibody (catalogue number ab131442, abcam, Cambridge, UK). Sections for immunohistochemical stains were boiled for 10 minutes in $10 \mathrm{Mm}$ citrate buffer (catalogue number AP9003-125) at $\mathrm{pH} 6$ for antigen retrieval then incubated for 1hour with the primary antibody. Ultravision detection system (catalogue number TP-015-HD) was used to complete immunostaining. Mayer's hematoxylin (catalogue number TA-060-MH) was used for counterstaining. Citrate buffer, Ultravision detection system as well as Mayer's hematoxylin were purchased from Labvision Thermo Scientific (Fremont, California, USA). Positive reaction appears as brown nuclear reaction. To detect the specificity of the reaction, negative controls were done using the same steps but without addition of the primary antibody ${ }^{[27]}$.

- For electron microscopic studies, left ventricle specimens were cut into small pieces $(0.5-1.0 \mathrm{~mm} 3)$, prefixed in $2.5 \%$ glutaraldehyde for 2 hours then postfixed in $1 \%$ osmium tetroxide in $0.1 \mathrm{M}$ phosphate buffer at $\mathrm{pH} 7.4$ and $4{ }^{\circ} \mathrm{C}$ for two hours. Specimens were then dehydrated and embedded in epoxy resin to obtain resin blocks ${ }^{[27]}$. Semithin $(1 \mu \mathrm{m})$ and ultrathin $(60-90 \mathrm{~nm})$ sections were cut using a Leica ultracut (UCT) (Glienicker, Berlin, Germany) at Electron Microscope Research Unit, Faculty of Agriculture, Cairo University. Semithin sections were stained with toluidine blue (1\%) and were examined by light microscope. On the other hand, ultrathin sections were stained with uranyl acetate followed by lead citrate and were examined and photographed by transmission electron microscope (TEM) (JEOL JEM-1400, Japan) ${ }^{[28]}$.

Telocytes, their telopodes and stem cells were digitally coloured, for their better visualization, using Adobe Photoshop CC 2017 v 18.0.

\section{Morphometric Studies}

Ten non-overlapping fields from different sections of each group were used to determine the following:

- Mean diameter of cardiomyocytes in 50 fibres for each group. It was measured as the distance between cardiomyocyte borders drawn through the nucleus (x400).

- Mean area percent of collagen fibres (x100).

- Mean number of p53 immunopositive cells (x400).

Measurements were carried out using Leica Qwin-500 LTD-software image analysis computer system Ltd. (Cambridge, England) at Histology Department, Faculty of Medicine, Cairo University.

\section{Statistical Analysis}

The morphometric measurements and the biochemical results were statistically analysed using "IBM SPSS statistics 21". Analysis was performed by One-way analysis of variance (ANOVA) followed by "Tuckey" post-hoc test to determine the statistical significance ( $P$ value $<0.05$ was considered significant). Data were presented as mean \pm standard deviation $(\mathrm{SD})^{[29]}$.

\section{RESULTS}

\section{General Observations}

No deaths were observed in all rats during the experiment. The control subgroups revealed comparable results so, they were collectively named control group. Likewise, fasting subgroups were collectively named fasting group. Diarrhea, determined by the need to change the animal cage, was observed in rats in DOX group following DOX administration.

\section{DOX and IF Effects on Body Weight (Table 1):}

Comparing baseline body weight in different groups at day 1 revealed non significant difference versus each other. On day 17, animals in group I (control group) and III (before staring DOX injection) showed increased body weight, animals underwent IF in groups II and IV showed less weight gain with non significant difference versus other groups.

On day 28 , control group showed progressive increase in body weight, however less weight gain was recorded in the remaining groups. Non significant difference was observed among control, fasting and fasting DOX groups. Animals received DOX in group III showed least body weight gain with significant decrease compared to control $(p<0.05)$ and non significant difference compared to group II and group IV (fasting DOX group).

\section{DOX and IF Effects on Cardiac Biomarkers (Troponin T, LDH, CPK) and OS Marker MDA (Table 2)}

At the end of the experiment, fasting group recorded non-significant decrease versus control group regarding 
the levels of Troponin T, LDH, CPK enzymes and MDA. In DOX group, their levels revealed a significant increase versus other groups $(p<0.05)$, whereas in fasting DOX group, their levels expressed significant decrease compared to DOX group $(p<0.05)$ and non-significant increase versus control group as well as fasting group.

\section{DOX and IF Effects on Autophagic Indicators (LC3II and p62) (Table 2)}

At the end of the experiment, fasting group recorded an elevation in LC3II level associated with decrease in p62 level compared to control group, but with non significant difference. Administration of DOX in group III (DOX group) induced pronounced increase in both LC3II and p62 levels and the difference was significant when compared to all other groups $(p<0.05)$. On the other hand, in fasting DOX group, both LC3II and p62 revealed significant decrease compared to DOX group $(p<0.05)$ and non significant increase versus control and fasting groups, although they did not completely revert back to control values.

\section{Histological Results}

\section{Control Group (group I)}

H\&E stained sections of control group revealed normal histological architecture in the form of branching and anastomosing cardiac muscle fibres in different directions. Muscle fibres had acidophilic sarcoplasm and single oval centrally located vesicular nuclei. Intercalated discs were hardly observed at interval as transversely running dark lines. Nuclei of connective tissue (CT) cells and blood vessels were noticed within the thin endomysium between myocytes (Figure 1.a)

In semithin sections, cardiomyocytes had single central pale oval nuclei with prominent nucleoli. The sarcoplasm revealed normal pattern of transverse striations and clearly observed intercalated discs that connect adjacent cells. Fibroblast and blood vessels were seen in the endomysium (Figure 1.b).

Mallory's trichrome stained sections showed fine blue stained collagen fibres in endomysium between the red stained cardiac muscle fibres and also around blood vessels (Figure 1.c).

Immunohistochemically stained sections with anti p53 showed negative immune reactions in nuclei of cardiomyocytes, endothelial cells and interstitial cells (Figure 1.d).

Ultrastructurally, cardiomyocytes had oval euchromatic nuclei with prominent nucleoli and filled with long parallel myofibrils (MF). The MF showed normal striations pattern with alternating dark bands (A), bisected by $\mathrm{M}$ lines, and light bands (I). In the middle of I bands appeared regular $(Z)$ lines demarcating regular sarcomeres. Rows of mitochondria $(\mathrm{m})$ were seen between MF and in the perinuclear area. T tubules of the diads were demonstrated at the level of the $\mathrm{Z}$ lines (Figures 2.a and 2.b). Intact intercalated discs with its desmosomes and adherens junctions were noticed (Figure 2.b). Telocytes were seen between cardiomyocytes as solitary oval cells with large euchromatic nuclei surrounded by cytoplasm. Telocytes had characteristic moniliform telopodes (Tps) extending from the cell body with variable length and width characterized by alternating thin segments (podomers) and thick segments (podoms). Telopodes; sometimes; appeared convoluted and branched around nearby blood vessel (Figure 2.c).

\section{Fasting Group (group II)}

Sections stained with H\&E (Figure 3.a), toluidine blue (Figure 3.b), Mallory's trichrome (Figure 3.c) and anti p53 immunohistochemical stains (Figure 3.d) showed histological features comparable with control group. Similarly, sections examined by TEM (Figures $4 . a$ and $4 . b$ ) revealed histological features similar to control group.

\section{DOX Treated Group (group III)}

Examination of H\&E stained myocardial sections of DOX treated group revealed separated cardiac muscle fibres. Additionally, many fibres appeared degenerated with vacuolated sarcoplasm devoid of nuclei and some fibres had focal areas of deeply stained homogenous acidophilic sarcoplasm. Congested blood vessels, extravasated red blood cells (RBCs) and inflammatory infiltrate were also observed (Figure 5.a).

In semithin sections, the sarcolemma appeared wavy and disrupted. Cardiac muscle fibres had disrupted poorly organized transverse striations, and areas of rarefaction that appeared as homogenous pale blue areas with scanty striations especially under the sarcolemma. Vacuolations and interrupted intercalated discs were also noticed. Nuclei of some myocytes had irregular or disrupted nuclear membranes and other nuclei appears small with dark peripheral clumped chromatin. Additionally, wide interfibres spaces, congested blood vessels with dark endothelial nuclei and Inflammatory infiltrate were detected (Figure 5.b).

Mallory's trichrome stained sections showed obvious deposition of blue stained collagen fibres between cardiac muscle fibres and around blood vessels (Figure 5.c).

Examination of p53 Immunohistochemically stained sections revealed multiple positive nuclei in cardiomyocytes, endothelial cells and interstitial cells (Figure 5.d).

Ultrastructurally, the sarcolemma appeared wavy and irregular. Nuclei of some myocytes appeared small. Clumps of heterochromatin, peripheral margination of chromatin against nuclear membrane and fragmentation and formation of small condensed chromatin balls (masses) were seen. Additionally, nuclear membranes appeared irregular and or disrupted. Myofibrils and sarcomeres were poorly organized with many interrupted $\mathrm{Z}$ lines. 
Focal areas of destructed MF or rarefaction of sarcoplasm especially around the nucleus and under the sarcolemma were observed. Moreover, distorted mitochondria with abnormal shapes and disrupted membranes forming clusters under the sarcolemma and between MF were observed. Also, autophagososomes (AP) with accumulation of undegraded cell debris (degenerated mitochondria) were seen between the MF. Furthermore, there were many dilated and disorganized T-tubules and distorted, non continuous dilated intercalated discs with areas devoid of cellular junctions. Increased collagen fibrils were also noticed between cardiomyocytes. The endothelial nucleus of blood vessels appeared irregular, indented with more heterochromatin in addition to, endothelial membrane bleb (Figures 6.a-c and Figure7.a). Telocytes with apoptotic heterochromatic nuclei and thin telopodes were seen between cardiomyocytes. Their telopodes surrounded cell debris contained degenerated muscle fibres (degenerated mitochondria and apoptotic bodies) (Figure 7.b).

\section{Fasting DOX Group (group IV)}

Sections stained with H\&E (Figure 8.a) and toluidine blue (Figure 8.b) showed apparently normal histological features except for the presence of few darkly stained nuclei, irregular nuclear membranes and some areas of poorly organized or disrupted transverse striations. In addition, mast cells with their specific metachromatically stained granules were noticed.

Additionally, Mallory's trichrome stained sections showed scattered collagen fibres between muscle fibres and around blood vessels (Figure 8.c).

Immunohistochemically stained sections with anti p53 showed positive immunoreactions in some nuclei of cardiomyocytes, endothelial cells and interstitial cells (Figure 8.d).
Regarding sections examined by TEM, they revealed apparently normal histological features except for the presence of small areas of degenerated MF, dilated $\mathrm{T}$ tubules and areas of nuclear membranes irregularities. In addition, fusion of lysosomes with mitochondria was observed (Figures 9.a-c).

Telocyte was seen in the endomysium between cardiomyocytes as large oval cell with large euchromatic nucleus and prominent nucleolus surrounded by cytoplasm. Expanded podom segments of telopodes; containing vesicles, multivesicular bodies and electron dense granules, were seen extending from the cell body and forming sheath around adjacent blood vessels in direct contact with its endothelial lining. Telocytes established direct contact with cells resembling stem cells, appeared small with intended heterochromatic nuclei and high nucleocytoplasmic ratio and present close to blood vessel. Telocytes were also seen communicating with each other by direct contact via their telopodes (Figures 10.a and 10.b).

\section{Effect on Morphometric Results (Table 3)}

Non significant difference was recorded in fasting group versus control group regarding all morphometric parameters. The mean diameter of cardiomyocytes in DOX group revealed a significant decrease compared to other groups $(p<0.05)$. On the other hand, fasting DOX group recorded non significant decrease versus control group and fasting group and significant increase compared to DOX group $(p<0.05)$. Regarding the mean area percent of collagen fibres and the mean number of $\mathrm{p} 53$ positive cells in DOX group, they showed a significant increase versus other groups $(p<0.05)$. However, fasting DOX group recorded significant decrease in these parameters compared to DOX group $(p<0.05)$ and non significant increase when compared with control group and fasting group. 

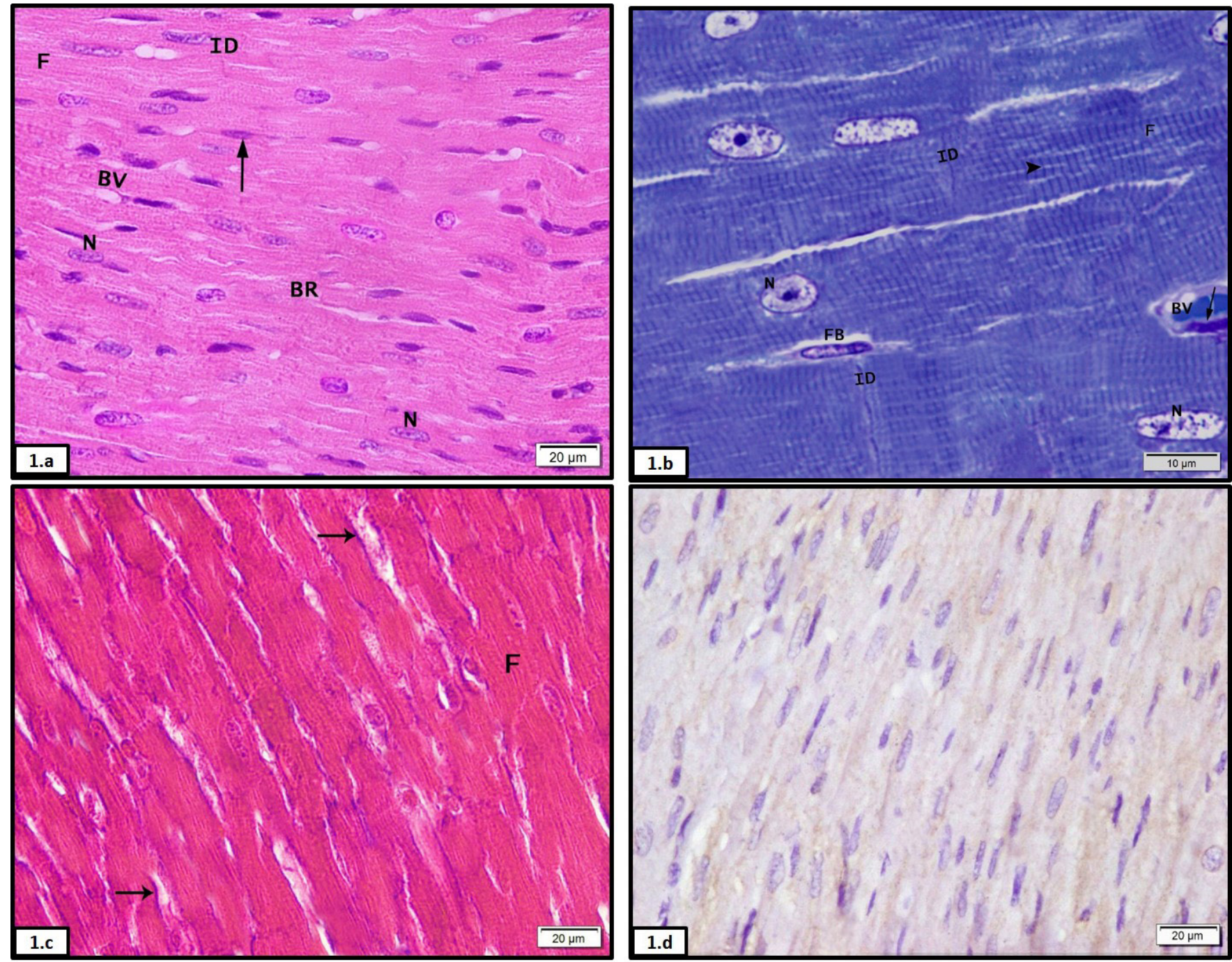

Fig. 1: Photomicrographs of the control myocardial sections showing: a: Longitudinal striated branching (BR) muscle fibres (F) with acidophilic sarcoplasm, single pale central oval nucleus (N) and intercalated disc (ID). Notice fibroblast's nuclei (arrow) and blood capillaries (BV) in the thin interfibres spaces [H\&E, $\mathrm{x} 400]$. b: Muscle fibres (F) appear branching with central pale oval nuclei (N) with prominent nucleoli, normal pattern of transverse striations (arrow head) and clearly observed intercalated discs (ID). Fibroblast (FB), and blood vessel (BV) lined by endothelium (arrow) can also be noticed [Toluidine blue, x1000]. c: Fine blue stained collagen fibres (arrows) in the endomysium between the red stained cardiac muscle fibres (F) [Mallory's trichrome stain, $\mathrm{x} 400$ ]. $\mathrm{d}$ : Negative p53 immunoreaction in nuclei of cardiomyocytes, endothelial cells and interstitial cells [anti p53 immunohistochemical stain, $\mathrm{x} 400$ ]. 

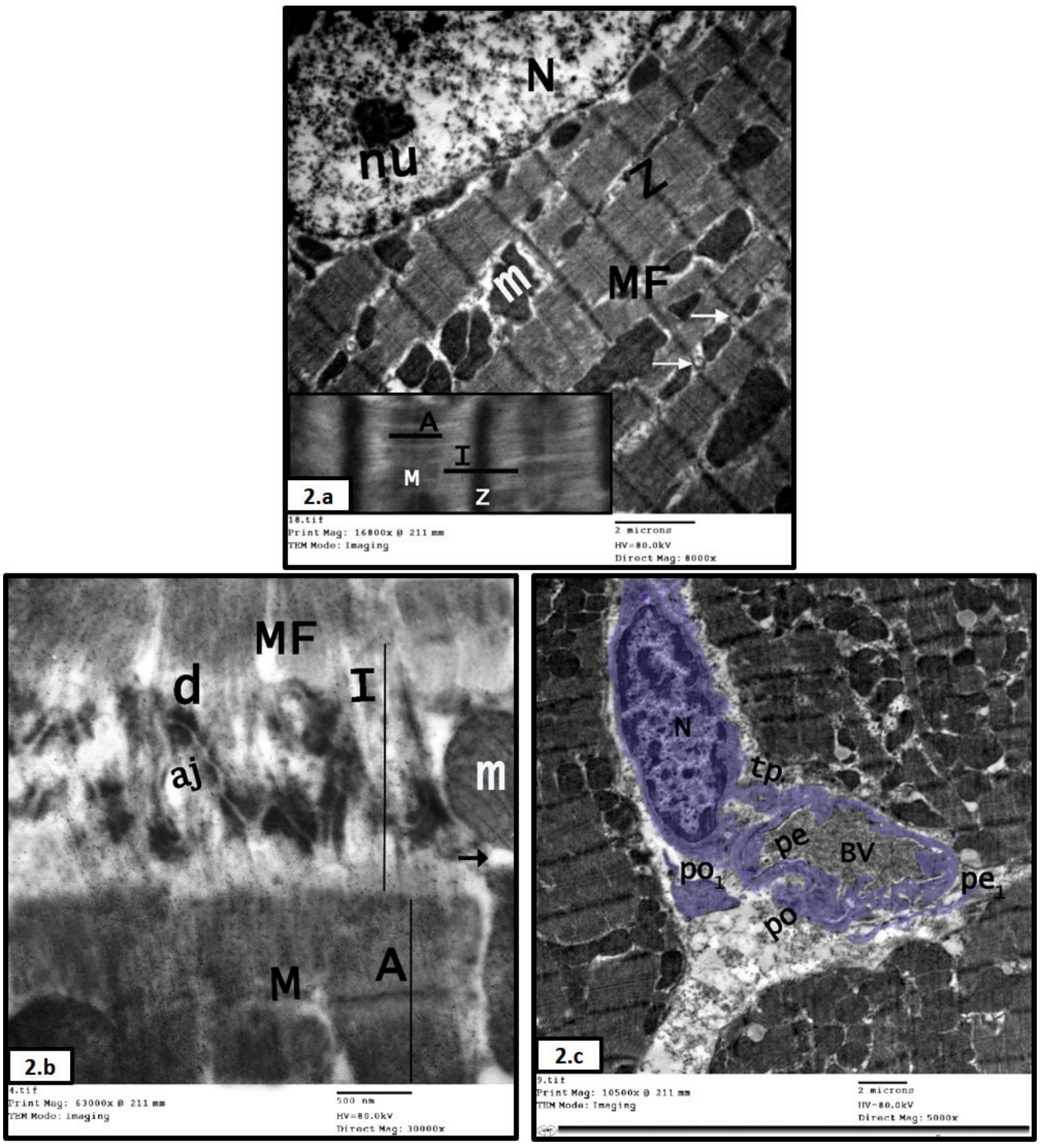

Fig. 2: TEM photomicrographs revealing: a: Cardiomyocyte filled with long parallel myofibrils (MF) and has oval euchromatic nucleus (N) with prominent nucleolus (nu). Rows of mitochondria (m) are seen between MF and also in the perinuclear area. Apparently normal $\mathrm{T}$ tubules (arrows) of the diads are noticed at the level of the $\mathrm{Z}$ lines $(\mathrm{Z})$ that bound regular sarcomeres. Inset shows the alternating light I bands (I) and dark A bands (A) with dark M line (M) $[\mathrm{x} 8000$, inset $x 15000]$. b: Intact intercalated disc with its desmosomes (d) and adherens junctions (aj) is seen at the level of $Z$ line. Notice the presence of myofibrils (MF) with alternating dark A band (A) bisected by M line (M), and light I band (I). In addition to mitochondria (m) with normal cristae and apparently normal T tubule (arrow) [x30000]. c: Telocyte (digitally colored blue) is seen in the endomysium between cardiomyocytes as solitary oval cell with large euchromatic nucleus $(\mathrm{N})$ surrounded by cytoplasm. Moniliform telopodes (tp) characterized by alternating thin podomers segments (pe) and thick podoms segments (po) are seen extending from the cell body and surrounding nearby blood vessel (BV).Notice the presence of another podomer $\left(\mathrm{pe}_{1}\right)$ and podom $\left(\mathrm{po}_{1}\right)$ segments $[\mathrm{x} 5000]$. 

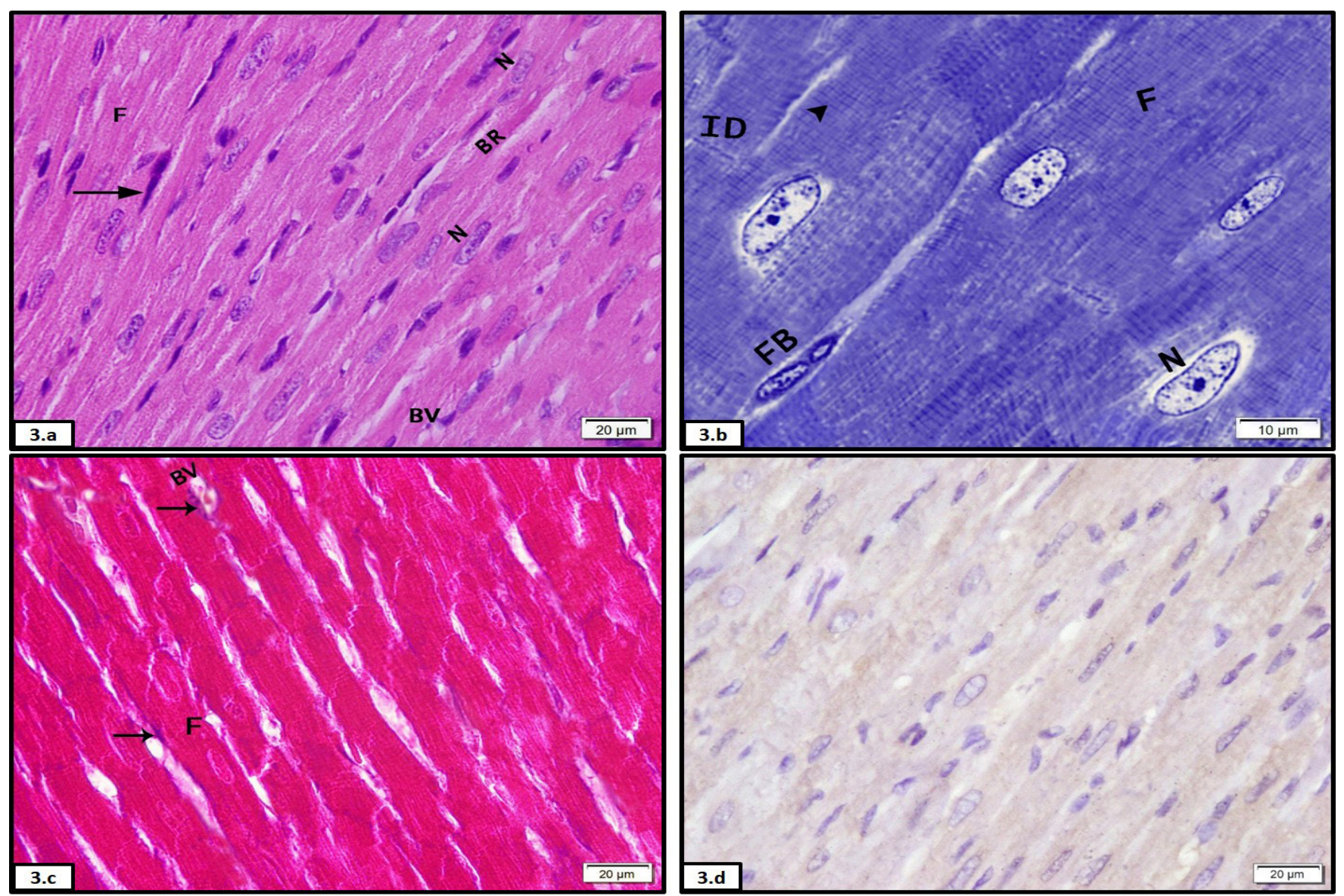

Fig. 3: Photomicrographs of myocardial sections from fasting group illustrating: a: Longitudinally oriented striated branching (BR) muscle fibres (F) with acidophilic sarcoplasm and pale central oval nuclei (N). Nuclei of fibroblasts (arrow) and blood capillaries (BV) are seen [H\&E, x400]. b: Branching muscle fibres (F) with central pale oval nuclei (N) and prominent nucleoli, normal pattern of transverse striations (arrow head) and intercalated discs (ID). Fibroblast (FB) can also be seen [Toluidine blue, x1000]. c: Few thin blue stained collagen fibres (arrows) in the endomysium between the regularly arranged cardiac muscle fibres (F) as well as around blood vessels (BV) [Mallory's trichrome stain, x400]. d: Negative p53 immunoreaction in nuclei of cardiomyocytes, endothelial cells as well as interstitial cells [anti p53 immunohistochemical stain, $x 400$ ].
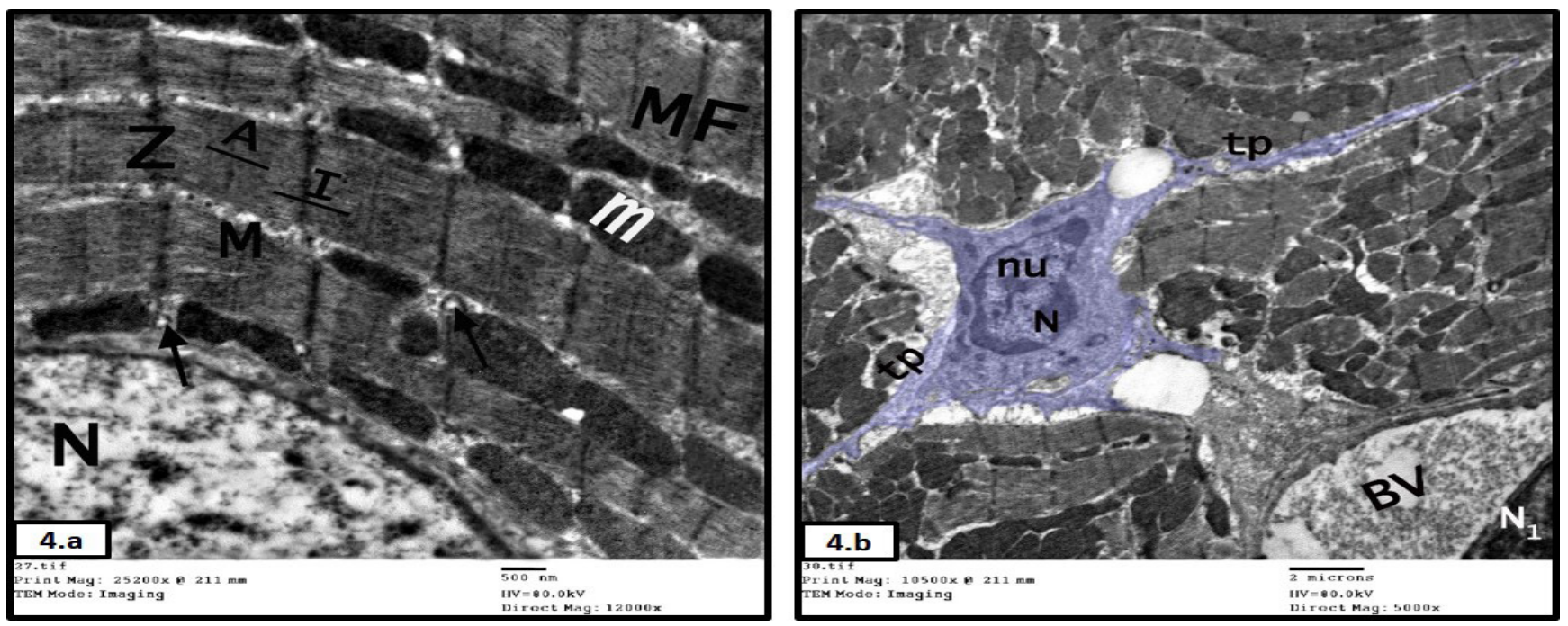

Fig. 4: TEM photomicrographs of myocardial sections from fasting group showing a: Cardiomyocyte with euchromatic nucleus (N), filled with well organized myofibrils (MF) having alternating light I bands (I) and dark A bands (A) with dark M line (M). Note the existence of apparently normal T tubules (arrows) at the level of the $\mathrm{Z}$ lines (Z) that demarcate regular sarcomeres. Rows of mitochondria (m) are situated between the MF and also in the perinuclear area [x12000]. $\mathrm{b}$ : Telocyte (digitally colored in blue) is seen in the endomysium as large triangular cell with large euchromatic nucleus (N) with prominent nucleolus (nu) surrounded by cytoplasm. Telopodes (tp) extend from the cell body between cardiomyocytes. Blood vessel (BV) and endothelium nucleus (N1) are seen [x5000]. 

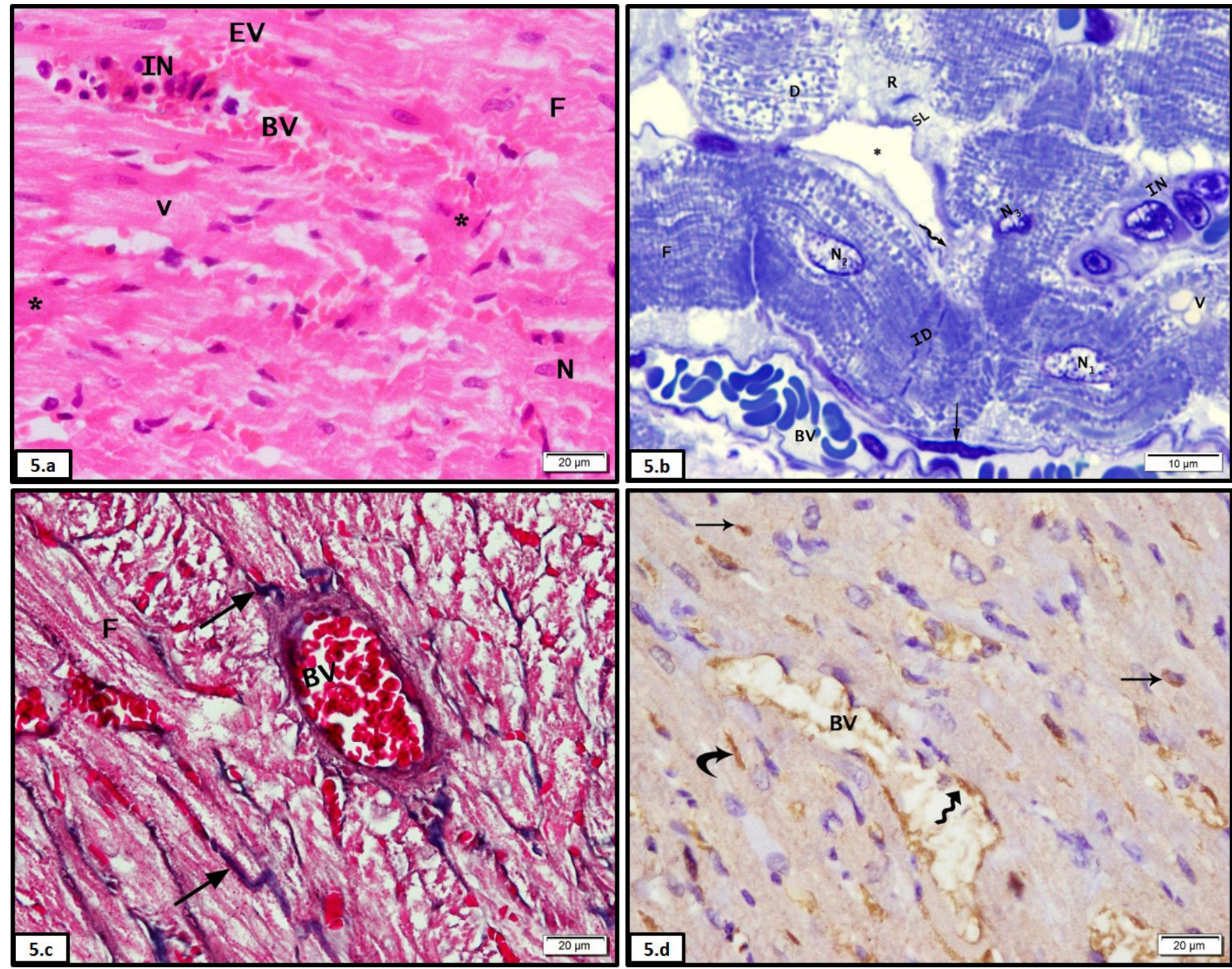

Fig. 5: Photomicrographs of the DOX group's myocardial sections demonstrating: a: Separated cardiac muscle fibres (F) with vacuolated sarcoplasm (V) and focal deeply stained homogenous acidophilic areas $(*)$ devoid of nuclei. Some myocytes' nuclei (N) are apparently normal. Congested blood vessels (BV), extravasated RBCs (EV) and inflammatory infiltrate (IN) are observed [H\&E, x400]. b: Wavy cardiac muscle fibres (F) with disrupted poorly organized transverse striations (D), pale blue homogenous rarified areas (R) nearly devoid of striations, vacuolations (V) and interrupted intercalated disc (ID). The sarcolemma (SL) appears wavy and disrupted (wavy arrow). Nuclei appear irregular (N1), with disrupted nuclear membrane (N2) \&shrunken with dark peripheral clumped chromatin (N3). Congested blood vessel (BV) having dark endothelial nucleus (arrow) and inflammatory infiltrate (IN) are seen. Notice, wide interfibres spaces $(*)$ [Toluidine blue, x1000]. c: Wide spread collagen fibres (arrows) deposition between the cardiac muscle fibres (F) and around blood vessels (BV). [Mallory's trichrome stain, $\mathrm{x}$ 400]. d: Numerous p53 positive nuclei in cardiomyocytes (arrows), endothelial cells (wavy arrow) of blood vessels (BV) and interstitial cells (curved arrow) [anti p53 immunohistochemical stain, $x 400]$. 

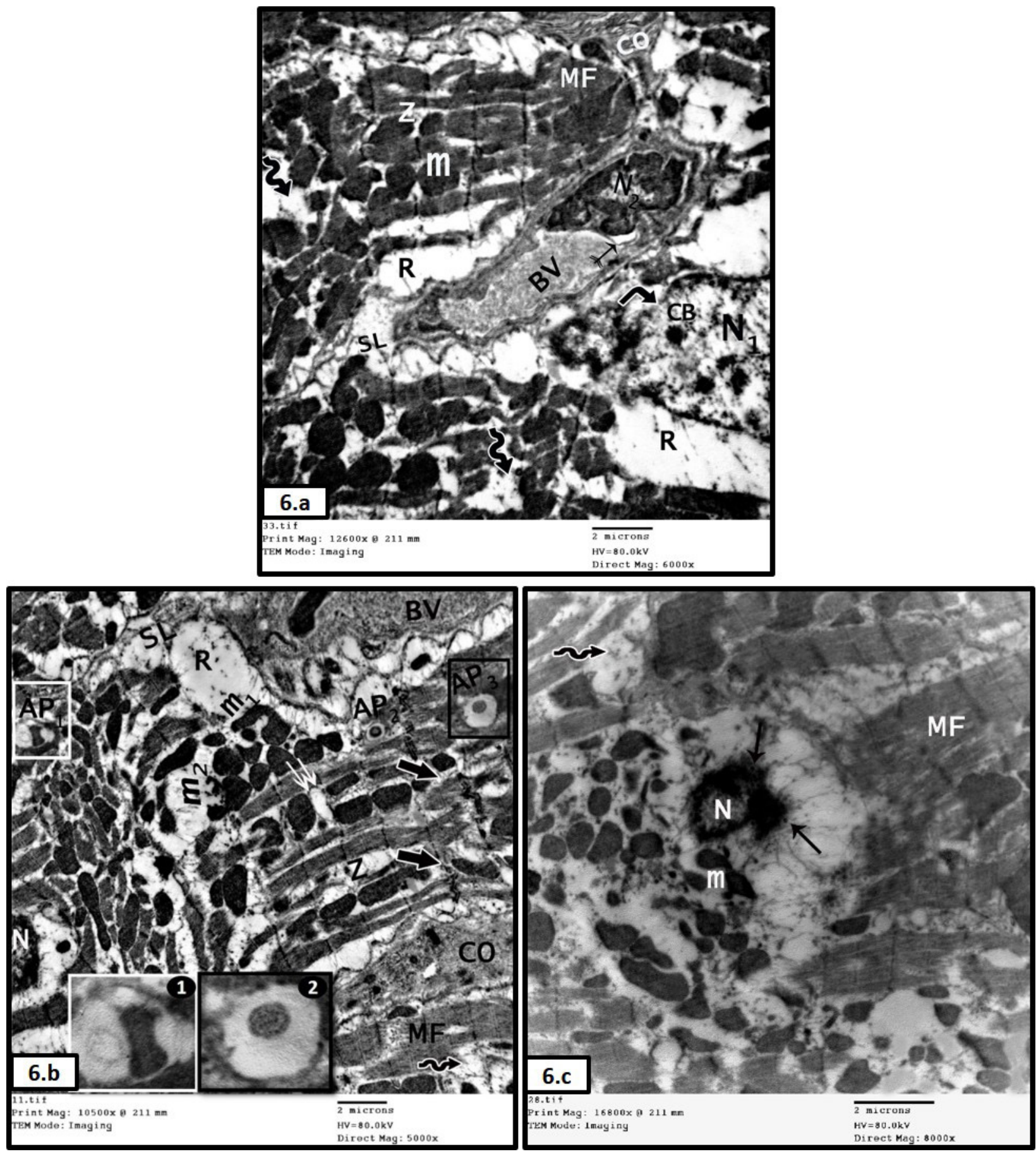

Fig. 6: TEM photomicrographs of group III sections showing: a: Wavy irregular sarcolemma (SL) with widening of sub sarcolemmal space. Myofibrils (MF) with interrupted $Z$ lines $(Z)$, focal areas of destructed MF (wavy arrows) or rarefaction $(\mathrm{R})$. Mitochondria (m) are also noted. Apoptotic cardiomyocyte's nucleus (N1) containing small condensed clumps of chromatin forming chromatin balls (CB) and having disrupted nuclear membrane (right angled arrow). Collagen fibrils (CO) deposition between cardiomyocytes, endothelial nucleus (N2) of the blood vessel (BV) appears irregular, indented with more heterochromatin and with cell membrane bleb (arrow with striked end). [X6000]. b: Wavy irregular sarcolemma (SL). Myofibrils (MF) with interrupted Z lines (Z), interrupted intercalated disc (arrows), focal areas of destructed MF (wavy arrow) or rarefaction (R) and dilated T tubule (double arrows). Cluster of distorted mitochondria with abnormal shape ( $\mathrm{m} 1)$ under the sarcolemma is noted, one of them has disrupted membrane (m2). It also reveals autophagososomes (AP1, AP2and AP3) with accumulation of undegraded cell debris. Degenerated mitochondria are seen in AP1 (inset 1) and AP3 (inset 2). Notice, part of cardiomyocyte's nucleus (N), blood vessel (BV) and collagen fibrils (CO) deposition among cardiomyocytes [x5000 \&insets: x10000]. c: Small apoptotic cardiomyocyte's nucleus (N) with clump of heterochromatin, peripheral chromatin margination against nuclear membrane and fragmentation (arrows) . Myofibrils (MF) with focal areas of destruction (wavy arrow), Mitochondria (m) with variable sizes and shapes [x8000]. 

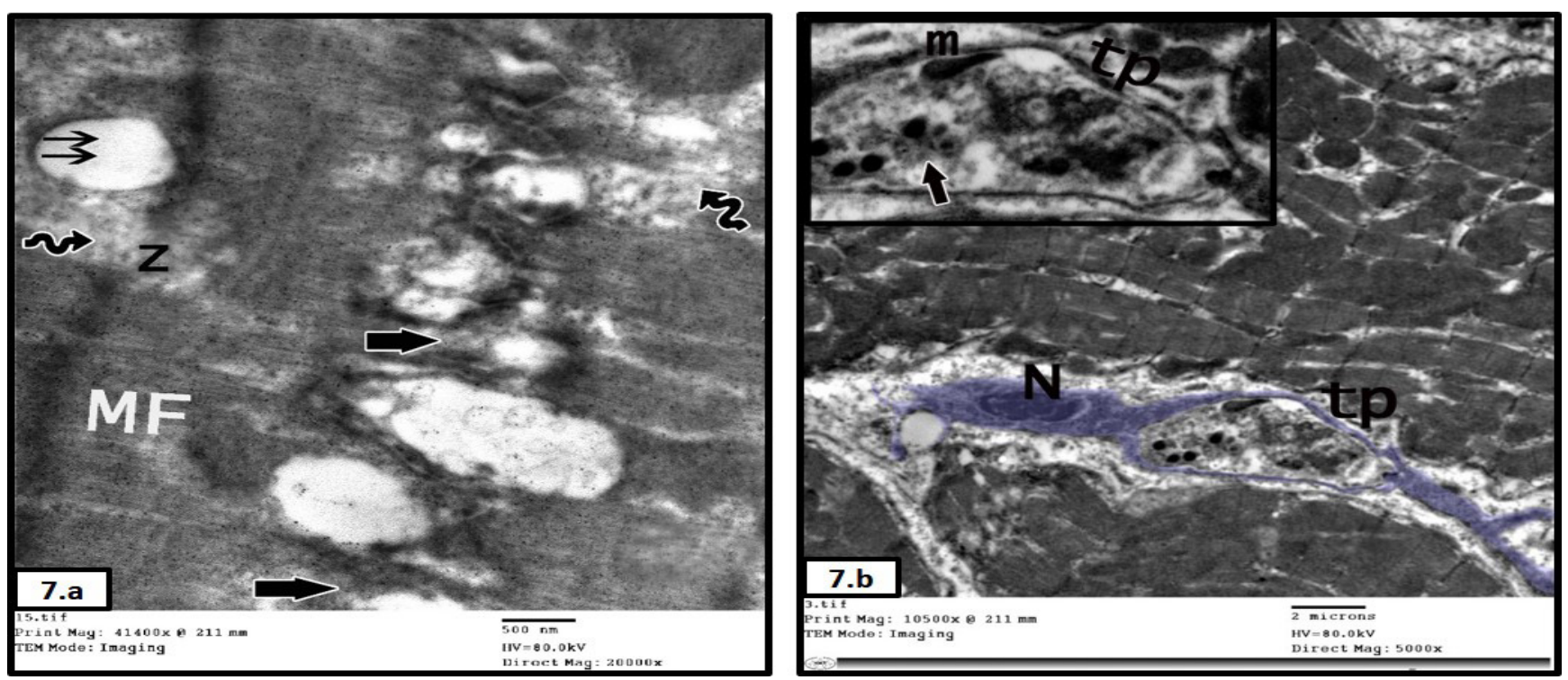

Fig. 7: TEM photomicrographs of group III sections illustrating: a: Distorted, non continuous and dilated intercalated disc with areas devoid of cellular junctions (arrows). Myofibrils (MF) with interrupted Z lines (Z), focal areas of destruction (wavy arrows) and dilated $\mathrm{T}$ tubule (double arrows) are observed [x20000]. b: Telocyte (digitally colored blue) in the endomysium between cardiomyocytes with small cell body, apoptotic heterochromatic nucleus (N) and thin branching telopodes (tp). Telopodes are surrounding cell debris from degenerated myofibrils which contain degenerated mitochondrion (m) and small electron dense chromatin balls surrounded by condensed cytoplasmic components forming apoptotic bodies (thick arrow) [x5000 \& inset: x10000].
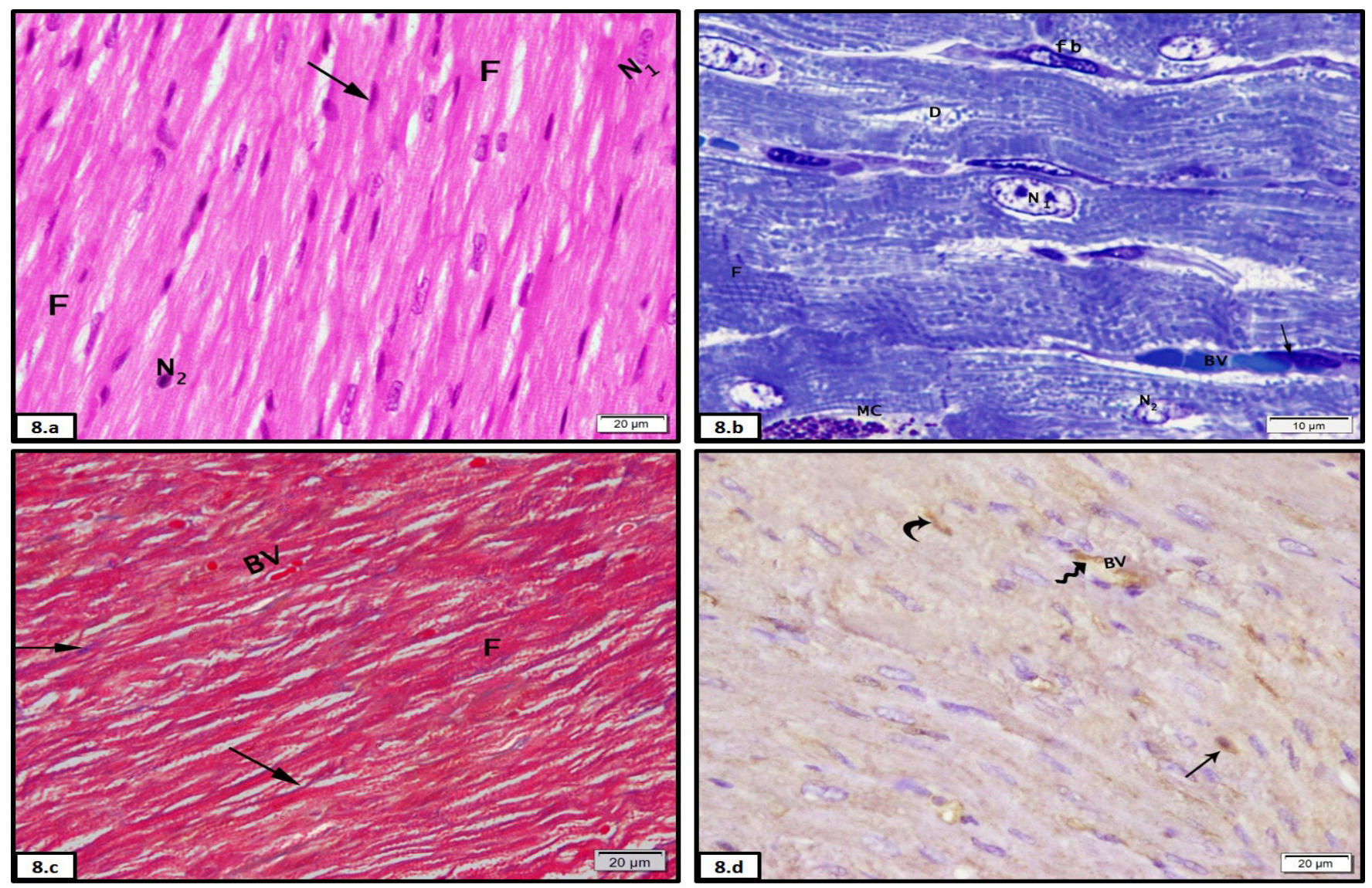

Fig. 8: Photomicrographs of fasting DOX group (group IV) myocardial sections showing: a: Apparently normal histological features of muscle fibres (F) and nuclei (N1) except for the presence of some darkly stained nuclei (N2). Notice fibroblasts nuclei between the muscle fibres (arrow) [H\&E, x400]. b: Muscle fibres (F) having nearly normal appearance with small areas of poorly organized or disrupted transverse striations (D). Most nuclei are with normal appearance (N1) and few with irregular nuclear membranes (N2). Fibroblasts (FB), and a mast cell (MC) with metachromatically stained dispersed granules and blood vessel (BV) lined by endothelium (arrow) are also noticed [Toluidine blue, x1000]. c: Few blue stained collagen fibres (arrows) in the endomysium between muscle fibres (F) and around blood vessels (BV) [Mallory's trichrome stain, $x$ 400]. d: Positive p53 immunoreactions in some nuclei of cardiomyocytes (arrow), endothelial cells (wavy arrow) of blood vessels (BV) and interstitial cells (curved arrow) [anti p53 immunohistochemical stain, x400]. 



Fig. 9: TEM photomicrographs of fasting DOX group sections illustrating: a: Few areas of degenerated and disrupted (wavy arrows) myofibrils (MF). Z lines $(\mathrm{Z})$, mitochondria $(\mathrm{m})$ and apparently normal euchromatic nucleus $(\mathrm{N})$ with prominent nucleolus (nu). Notice lysosomes (L) fusion with mitochondria [x6000]. b: Few areas of degenerated and disrupted (wavy arrow) myofibrils (MF), apparently normal T tubule (arrow) and another dilated (double arrows) one. Mitochondria (m), Z lines (Z) and M lines (M) are seen [x15000]. c: Apparently normal intercalated disc with its desmosomes (d), mitochondria (m), Z lines $(\mathrm{Z})$, and apparently normal myofibrils (MF) with small degenerated areas (wavy arrow) [x25000]. 

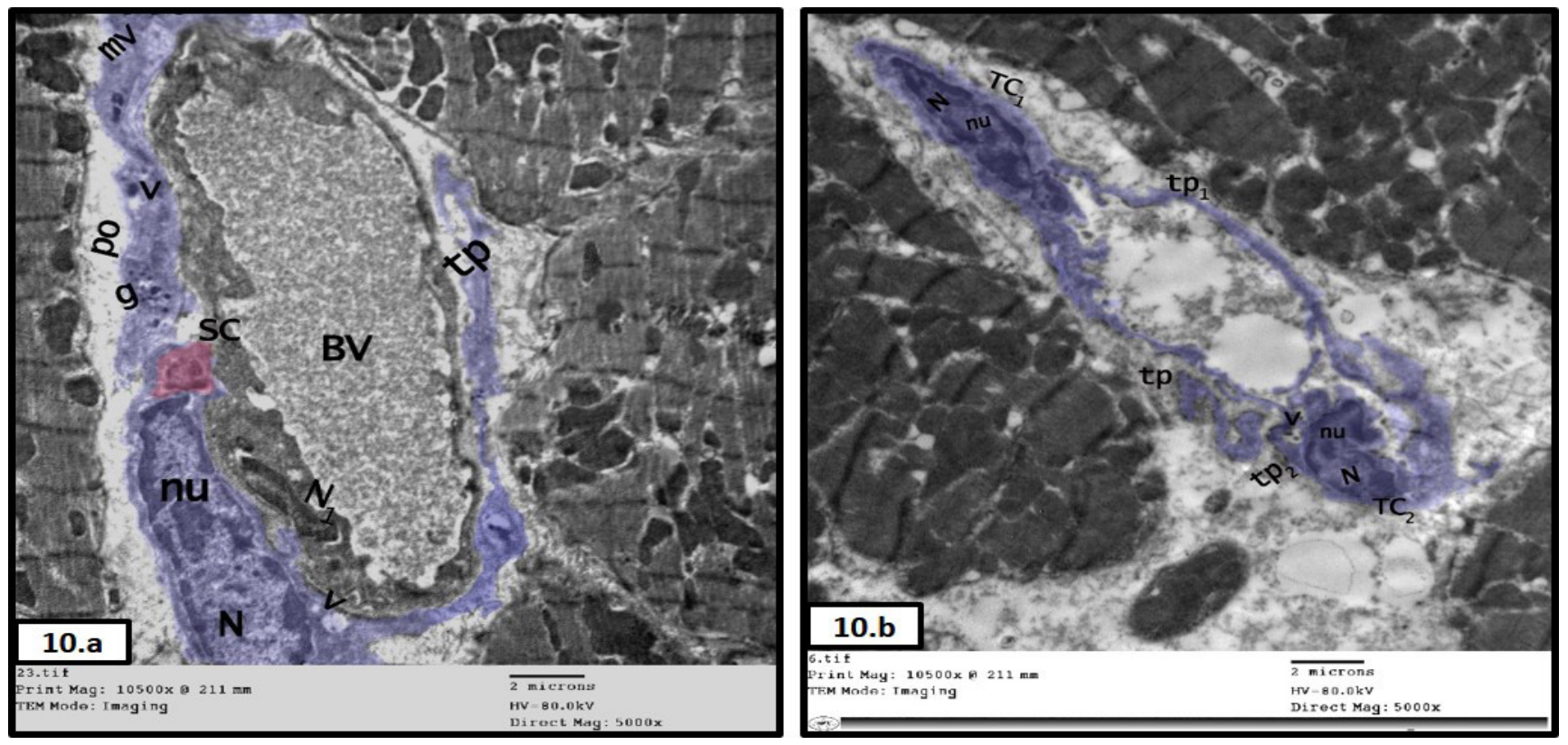

Fig. 10: TEM photomicrographs of fasting DOX group sections revealing: a: Telocyte (digitally colored blue) is seen between cardiomyocytes as large oval cell with large euchromatic nucleus $(\mathrm{N})$ and prominent nucleolus (nu) surrounded by cytoplasm. Thick expanded podom segments (po), packed by vesicles (v), multivesicular body (mv) and electron dense granules (g), are seen extending from the cell body and forming sheath around blood vessel (BV) in direct contact with its endothelium. Telocyte established direct contact with small cell (digitally colored red) present close to BV, has intended nucleus with peripheral heterochromatin and high nucleocytoplasmic ratio; suggesting character of stem cell (SC). Notice the presence of another telopode (tp) and nucleus of endothelial cell $\left(\mathrm{N}_{1}\right)$ [x5000]. b: Two telocytes $\left(\mathrm{TC}_{1} \& \mathrm{TC}_{2}\right.$ ) (digitally colored blue) are seen in the endomysium between cardiomyocytes as fusiform cells (lower one is folded) with large euchromatic nuclei $(\mathrm{N})$ and prominent nucleoli $(\mathrm{nu})$ surrounded by cytoplasm. Their telopodes $\left(\mathrm{tp}_{1} \& \mathrm{tp}_{2}\right.$ ) establish direct contact with each other. Notice the presence of vesicle (V) in $\mathrm{tp}_{2}$ and presence of another telopode (tp) [x5000].

Table 1: Mean value $\pm \mathrm{SD}$ of body weight in all groups

\begin{tabular}{lcccc}
\hline $\begin{array}{c}\text { Body weight } \\
\text { in gm }\end{array}$ & Group I & Group II & Group III & Group IV \\
\hline Day 1 & $202 \pm 8.3$ & $201 \pm 5.4$ & $201 \pm 5.3$ & $201 \pm 6.3$ \\
Day 17 & $236.3 \pm 8.3$ & $232.5 \pm 5$ & $235.4 \pm 4.9$ & $231.6 \pm 6$ \\
Day 28 & $258.3 \pm 8.3$ & $252.1 \pm 5$ & $246.7 \pm 5.7^{*}$ & $251.5 \pm 5$ \\
\hline
\end{tabular}

* Significant $(P<0.05)$ as compared to control group at day 28

Table 2: Mean value \pm SD of biochemical parameters in all groups

\begin{tabular}{ccccc}
\hline Parameters & Group I & Group II & Group III & Group IV \\
\hline $\begin{array}{c}\text { Troponin-T } \\
\text { (ng/ml) }\end{array}$ & $0.86 \pm 0.33$ & $0.83 \pm .0 .8$ & $3.7 \pm 0.5^{*}$ & $0.95 \pm 0.06^{\square}$ \\
LDH (U/L) & $248.9 \pm 21.2$ & $235.1 \pm 18.6$ & $599.1 \pm 82^{*}$ & $287.69 \pm 54^{\square}$ \\
CPK (U/L) & $72.6 \pm 5.7$ & $74.9 \pm 4$ & $240.8 \pm 28^{*}$ & $100.09 \pm 18^{\square}$ \\
MDA level & $28.3 \pm 3.8$ & $27.9 \pm 3.3$ & $70.4 \pm 1.8^{*}$ & $31.9 \pm 4.7^{\square}$ \\
(nmol/g) & & & & \\
LC3II & $1.15 \pm 0.36$ & $1.24 \pm 0.34$ & $4.1 \pm 0.38^{*}$ & $1.58 \pm 0.34^{\square}$ \\
p62 & $0.53 \pm 0.04$ & $0.51 \pm 0.01$ & $2.17 \pm 0.22^{*}$ & $0.59 \pm 0.02^{\square}$ \\
\hline
\end{tabular}

* Significant $(P<0.05)$ as compared to other groups.

$\square$ Significant $(P<0.05)$ as compared to DOX group.
Table 3: Mean value \pm SD of morphometric parameters in all groups

\begin{tabular}{|c|c|c|c|c|}
\hline Parameters & Group I & Group II & Group III & Group IV \\
\hline $\begin{array}{c}\text { The mean } \\
\text { diameter of } \\
\text { cardiomyocytes } \\
(\mu \mathrm{m})\end{array}$ & $11.7 \pm 1.1$ & $11.6 \pm 1.8$ & $6.8 \pm 0.80^{*}$ & $10.9 \pm 0.4$ \\
\hline $\begin{array}{l}\text { Mean area \% } \\
\text { of collagen } \\
\text { fibres }\left(\mu \mathrm{m}^{2} \%\right)\end{array}$ & $6.58 \pm 2.1$ & $6.7 \pm 1.3$ & $49.1 \pm 4^{*}$ & $8.1 \pm 1.9^{\square}$ \\
\hline $\begin{array}{c}\text { number of P53 } \\
\text { positive cells }\end{array}$ & $0.8 \pm 0.63$ & $0.7 \pm 0.48$ & $5.3 \pm 2.2^{*}$ & $1.2 \pm 0.9^{\square}$ \\
\hline \multicolumn{5}{|c|}{ * Significant $(P<0.05)$ as compared to other groups. } \\
\hline \multicolumn{5}{|c|}{$\square$ Significant $(P<0.05)$ as compared to DOX group. } \\
\hline \multicolumn{5}{|l|}{ DISCUSSION } \\
\hline
\end{tabular}

Doxorubicin is an important anticancer drug. Unfortunately, its main side effect is cardiotoxicity that may be severe enough limiting its use. Recently DOX cardiotoxicity has become more prevalent as cancer survival rates are increasing ${ }^{[30]}$. A rat model of DOX cardiotoxicity was created in this study through injection of $18 \mathrm{mg} / \mathrm{kg}$ DOX as accumulative dose. This was chosen 
as previous studies verified that cardiotoxicity can be induced by cumulative DOX dose $15-25 \mathrm{mg} / \mathrm{kg}^{[31]}$.

In the present work, DOX cardiotoxicity was proved biochemically in DOX group by significant elevation in serum levels of cardiac enzymes; LDH and CPK, and Troponin $\mathrm{T}$ level. They are considered the best cardiac injury biomarkers as they leak from mitochondria following damage of cardiomyocytes ${ }^{[32]}$.

Further reinforcement to the development of DOX cardiotoxicity came from severe affection of cardiac muscle fibres in the form of cardiomyocyte's degeneration, cytoplasmic vacuolations and pyknotic nuclei. Ultrastructurally, this damage was more evident as, degenerated MF, sarcoplasmic rarefaction, ill defined sarcomeres, distorted mitochondria, interrupted $\mathrm{Z}$ lines and intercalated discs, dilated tubular system and irregularity of sarcolemma. Such findings were supported by and provided explanation for the significantly decreased cardiomyocytes diameter in DOX group and were consistent with other studies $^{[33-36]}$.

Oxidative stress is a key mediator for DOX cardiotoxicity ${ }^{[37]}$. Therefore, MDA level was measured in this work. It revealed significant elevation in DOX group versus control. Development of OS in this group was attributed to DOX accumulation in mitochondria as it has high affinity for cardiolipin present in the inner mitochondrial membranes producing highly toxic free radicals that react with the endogenous anti-oxidants causing their depletion. This, in turn, resulted in lipid peroxidation, protein oxidation and DNA damage with subsequent mitochondrial damage and cell death ${ }^{[38]}$. The presence of distorted mitochondria with abnormal shapes, disrupted membranes and autophagosomes contained degenerated mitochondria in DOX group in the current work reflected that they are the major target for DOX cardiotoxicity.

It was assumed that the excessive OS by products from damaged mitochondria aid the trigger of apoptosis cascade and cell death ${ }^{[39]}$. Moreover, DOX itself could stimulatep53 activity in the heart and cause enzymatic pathways changes within cardiac muscle fibres resulting in direct cellular damage and apoptotic cell death ${ }^{[19]}$. This assumption was supported in the present work in DOX group by the presence of multiple characteristic features for apoptosis ${ }^{[40]}$ like small dark irregular nuclei, chromatin clumping, margination against nuclear membranes, fragmentation and formation of small chromatin balls, disrupted nuclear membranes, cytoplasmic vacuolations, convolution of cardiomyocytes outlines with irregular disrupted sarcolemma and appearance of apoptotic bodies. Likewise, apoptotic features were also detected in endothelial nuclei in DOX group. More reinforcement came from positive expression of p53 in these cells with significant increase in their number versus other groups. This finding was similarly reported in a prior study ${ }^{[41]}$.
Recently, cardiac endothelial cells were specified as a target for DOX apoptosis directly or by generation of both reactive oxygen and nitrogen species which damage vital intracellular components of endothelial cells, release mitochondria cytochrome $\mathrm{C}$ and activate proapoptotic factors such as caspases ${ }^{[42]}$. Furthermore, DOX can reduce and dysregulate the secretion of endothelial cell paracrine factors such as, endothelin-1, neuregulin, nitric oxide and prostaglandin I2. These factors act directly on cardiomyocytes affecting their survival, functions, and homeostasis ${ }^{[42]}$. Bearing in mind that cardiac muscle is the most aerobic organ in the body having vasculature very rich in capillaries with muscle to capillary ratio $1: 1$ and a distance between capillary endothelial cell and the neighboring cardiomyocyte about $1 \mathrm{~mm}^{[43]}$. This could clarify the close relation between the two cells and their dependency on each other. For that reason, endothelial cell apoptosis in this group was supposed to cause and augment cardiomyocyte death.

Growing evidences revealed that dysregulation of autophagy may also play a contributing role in DOX induced cardiotoxicity ${ }^{[44]}$. Normally, a certain level of autophagy is maintained by cardiomyocytes to guarantee physiological degradation of aging and damaged organelles ${ }^{[45]}$. But with excessive stimuli, as in heart failure, autophagy became dysregulated and incapable of maintaining cardiomyocytes homeostasis ${ }^{[46]}$. In addition, the lysosomes became saturated and dysfunctional following peroxidation of their membranes by reactive oxygen species $(\operatorname{ROS})^{[47]}$.

In brief, the process of autophagy starts with formation of isolation membrane, phagophore, which engulf certain cargo (protein aggregates or damaged organelles like mitochondria) forming autophagosome (AP). The process is completed by fusion of AP with lysosomes to form autolysosomes where cargo is degraded by lysosomal enzymes $^{[48]}$. Therefore, to evaluate autophagic process in different groups, the present work selected electron microscopy as it is considered one of the most accurate methods for the detection of autophagy and autophagic accumulation $^{[49]}$, along with, two proteins, LC3II and p62. LC3II is considered the only reliable protein marker associated with autophagosomes formation ${ }^{[25]}$. Meanwhile, p62 is responsible for attraction of ubiquitinated cargo proteins to the autophagosomes facilitating their degradation by fusion with the lysosome and completion of autophagic process. Therefore, accumulation of $\mathrm{p} 62$ denotes inability to complete autophagic process ${ }^{[26]}$.

Examination of ultrathin sections of DOX group revealed accumulated autophagososomes, some of them contained degenerated mitochondria, with a significantly increased level of LC3-II protein expression indicating that DOX augmented the initiation of autophagy and mitophagy (selective elimination of damaged mitochondria by autophagy). However, there was also significant increase in the level of p62 signifying failure of their completion. This, in turn, result in accumulation of damaged mitochondria 
and protein aggregates. Bearing in mind that myocardial function and cell survival depend on a high content of healthy mitochondria to ensure adequate ATP production. So failure of mitophagy were proposed to hasten ROS overproduction, apoptotic cell death and contribute to DOX cardiotoxicity ${ }^{[50]}$. Such findings coincide with those recorded in former studies ${ }^{[5,32,51]}$ and were attributed to stimulation of specific autophagy signaling pathways by DOX induced OS, production of ROS and several inflammatory cytokines and DNA damage ${ }^{[52]}$. In contrast, decreased level of LC3-II protein expression was detected in another study suggesting that DOX treatment impaired the autophagic processes ${ }^{[53]}$.

The demonstrated inflammatory cell infiltration, congested blood vessels and extravasated RBCs in DOX group could be considered as a part of the inflammatory process that accompany DOX cardiotoxicity ${ }^{[36,54]}$ and was explained by the ability of DOX to enhance the activity of $\mathrm{NF}-\mathrm{\kappa B}$ which in turn stimulate production of high levels of pro-inflammatory cytokines such as TNF- $\alpha$, IL-1 $\beta$, IL-18, IL-6, nitric oxide and COX-2 ${ }^{[36]}$. Furthermore, this inflammation could be linked to failure of mitophagy completion detected in DOX group. This suggestion was strengthened, in a former study, by activation of Toll-like receptor 9, a major mediator that activate $\mathrm{NF}-\kappa \mathrm{B}$, in DOXinduced cardiotoxicity as a response to mitochondrial DNA escaped from autophagy with subsequent triggering of cardiac inflammation ${ }^{[55]}$.

DOX group also, revealed widening of intercellular spaces that could be considered as a sequel of apoptotic cell death. Also, obvious collagen fibres deposition and significant increase in area percent of collagen fibres were reported previously following DOX cardiotoxicity and considered as cardiac remodeling to replace damaged cardiomyocytes ${ }^{[36]}$. Fibrosis was also attributed to enhanced transformation of cardiac fibroblasts into myofibroblasts ${ }^{[56]}$.

Other essential finding reported in DOX group in this study was the presence of telocytes that appeared small, having small nuclei with marked heterochromatin and their telopodes appeared thin and delicate. Such findings indicated that telocytes were similarly deteriorated by DOX induced OS and suggested apoptotic death of them ${ }^{[57]}$. In view of telocytes as one of cardiac interstitial cells ${ }^{[5,59]}$, their apoptosis might be supported by and also explain the positive expression of p53 detected in interstitial cells in this group. Which, in turn, support the hypothesis that telocytes morphology could be affected by changes in their microenvironment ${ }^{[60]}$.

Furthermore, Tps of telocytes in DOX group were seen surrounding cell debris, most probably degenerated myofibrils with degenerated mitochondria and apoptotic bodies suggesting a trial of telocyte to localize the DOX induced degenerative and inflammatory processes. From the other point of view, deterioration of telocytes was supposed to augment DOX cardiotoxicity following loss of their role in cardiac homoeostasis and regeneration ${ }^{[58]}$.
In the same sequence, apoptosis of telocytes was recently reported as a cause for heart disease ${ }^{[59]}$.

Fasting has attracted attention as a promising preventive or therapeutic strategy for several types of heart diseases. It achieved cardioprotective effects against coronary heart disease, age-related cardiac hypertrophy and myocardial ischemic injury ${ }^{[15]}$. Moreover, it enhanced the efficacy of a variety of chemotherapeutic agents including DOX in the treatment of various tumour types with simultaneous protection of healthy cells from toxicity ${ }^{[6,62]}$. Therefore, IF was tried in this study as non pharmacological cardioprotective approach against DOX cardiotoxicity. Bearing in mind that, DOX is used in treatment of patients suffering from cancer who might suffer from malnutrition problems, therefore, IF could be considered more accessible approach for them than long term fasting. Intermittent fasting has three variants according to period of fasting to feeding; 20:4, 18:6 and 16:8 $8^{[63]}$. The 16:8 IF regimen was preferred in this study as it is more feasible for patients and easily applicable as a life style. Fasting for 16 hours could be achieved easily by 8 hours sleeping with fasting 4 hours before and 4 hours after.

In the current study, body weight revealed non significant difference between all groups at day 17 of experiment and also, between control, fasting and fasting DOX groups at day 28. This could be explained by the free food access without caloric restriction during the eight hours of feeding in fasting rats.

The least weight gain was recorded in DOX group (group III) at day 28 with significant decrease versus control. This could be attributed to nausea, vomiting and diarrhea that commonly associate with DOX. Remarkably, Fasting was reported to reduce incidence of such DOX side effects ${ }^{[64]}$. This could explain the non significant difference in weight recorded in fasting DOX group compared to control.

Biochemical as well as morphometric parameters of fasting group (group II) in the present work showed good records as compared to control group. This might be attributed to stimulation of autophagic process by fasting and elimination of damaged proteins and organelles within the cells ${ }^{[11]}$. This explanation was confirmed by the noted elevation of LC3II with simultaneous decrease in p62 in this group versus control.

In fasting-DOX group (group IV) of the present study, IF modulated the antioxidant status of the myocardium as proved by significant decrease in MDA level versus DOX group and the non significant increase compared to control group. Such finding indicated decreased rate of lipid peroxidation and revealed that IF can protect against DOX cardiotoxicity by lowering OS. This explanation was in line with several studies, which confirmed the antioxidative activity of fasting ${ }^{[37,65]}$.

Following lowering of OS by IF, its subsequent cardiac damage and apoptotic cell death were assumed 
to be suppressed. This assumption was enforced in the present study by almost normal histological architecture of myocardium except for the presence of few darkly stained nuclei, nuclear membranes irregularities and degenerated areas of MF. Further reinforcement came from non significant difference in cardiomyocytes diameter and area percent of collagen fibres versus control group, and the significant decrease in number of $\mathrm{p} 53$ positive cells compared to DOX group. Preservation of cardiac tissue was reflected on its biochemical markers that revealed significant decrease in cardiac enzymes, LDH and CPK and Troponin T levels versus DOX group with non significant difference compared to control group. This finding was reported formerly but with a different fasting regimen ${ }^{[37,66]}$.

Furthermore, in fasting- DOX group, there was significant decrease in level of LC3II and p62 compared to DOX group and non significant increase versus control. In addition, fused lysosomes with mitochondria were detected by electron microscopy. Such findings could suggest ability of IF to restore autophagy, initiation and completion, in this group. It was similarly reported in a prior study ${ }^{[37]}$ and explained by the ability of fasting to activate certain autophagy regulators and promote expression of certain genes that enhance degradation of abnormal proteins. During fasting hours, autophagy delays or prevents apoptosis by turning over nonessential cell constituents that could trigger cell death to provide cells with needed nutrients. Therefore, restoration of autophagy could provide further explanation for suppression of apoptosis in fasting DOX group, and was supposed to support and maintain cardiomyocyte structure and function ${ }^{[67]}$ and protect against DOX cardiotoxicity.

The present work assumed that, IF exerted similar protective effect on telocytes and activated them to share in cardiac support in fasting DOX group. Telocytes appeared in fasting-DOX group enlarged with euchromatic nuclei and long corrugated Tps. In addition, telocytes acquired signs of exaggerated secretory activities in this group. Their Tps became expanded and packed by electron dense granules, secretory vesicles and multivesicular bodies.

Telocytes share in cell communication via two methods: over long distances through their Tps, and over short distances via extracellular vesicles ${ }^{[68,69]}$. These vesicles may contain various growth factors or cytokines, which regulate their microenvironment ${ }^{[70]}$, and nearby cells by paracrine or juxtracrine mechanisms ${ }^{[71]}$ and through which they could influence cardiac repair and regeneration.

Therefore, further reinforcement for the previous assumption was the homocellular contact seen in this group between neighboring telocytes through their Tps and microvesicles. This contact was assumed to provide structural support between telocytes, allow transmission of intercellular signals and contribute to cardiac homeostasis, regeneration or repair ${ }^{[72,73]}$. Furthermore, this assumption could be strengthen also by the Tps that were seen forming a sheath around blood vessels and heterocellular contact with its lining endothelial cells. This contact with other cell types within the heart as cardiomyocytes, stem cells, mast cells, macrophages, fibroblasts, pericytes and endothelial cells was previously described ${ }^{[17]}$ and was proposed to allow telocytes to serve as transducing centers and provide cell singling via their Tps network to other cell types and structures ${ }^{[74]}$. In addition, more link was found between telocytes, endothelium development and induction of neoangiogenesis through release of signaling protein such as vascular endothelial growth factor following myocardial infarction ${ }^{[75]}$.

Taking into consideration that DOX cardiotoxicity could be mediated by depletion of stem cell pool and prevented by their restoration ${ }^{[76]}$; fasting could enhance stem cell function for repair and regeneration ${ }^{[77]}$ and telocytes were considered as nursing cells for cardiac stem cells ${ }^{[17]}$, the present work assumed that the direct communication that was detected in fasting DOX group between telocytes and stem cells might enforce the suggested role for telocytes in cardiac regeneration. Telocytes could provide stem cells with mechanical support, promote their migration, differentiation, proliferation and maturation ${ }^{[78]}$. In addition, it was also shown to support them to form cardiomyocytes, smooth muscle cells, endothelial cells and to integrate into cardiac architecture ${ }^{[79,80]}$.

In the same sequence, mast cells detected in semithin sections of the same group could be related to stem cells and cardiac repair since both cells are located in the perivascular area, and mast cells was previously reported to produce several cytokines, angiogenic factors and growth factors able to affect cardiac remodeling ${ }^{[81]}$, in addition to release of TGF- $\beta$ that can affect cardiac stem cells differentiation ${ }^{[82]}$.

\section{CONCLUSION}

DOX induced cardiotoxicity, at least in part, through OS, apoptosis of cardiomyocytes and telocytes and dysregulation of autophagy. Intermittent fasting could prevent this cardiotoxicity by restoration of oxidative state, attenuation of apoptosis, regulation of autophagic process and preservation of telocytes.

\section{CONFLICTS OF INTEREST}

There are no conflicts of interest.

\section{REFERENCES}

1. Damiani RM, Moura DJ, Viau CM, Caceres RA, Henriques JAP, Saffi J. Pathways of cardiac toxicity: Comparison between chemotherapeutic drugs doxorubicin and mitoxantrone. Arch Toxicol 2016; 90: 2063-2076.

2. Colombo A, Cipolla C, Beggiato M, Cardinale D. Cardiac toxicity of anticancer agents. Curr Cardiol Rep 2013; 15: 362.

3. Li DL, Hill JA: Cardiomyocyte autophagy and cancer chemotherapy. J Mol Cell Cardiol 2014; 71: 54-61. 
4. Shabalala S, Muller CJF, Louw J, Johnson R: Polyphenols, autophagy and doxorubicin-induced cardiotoxicity. Life Sci 2017; 180: 160-170.

5. Luo P, Zhu Y, Chen M, Yan H, Yang B, Yang X, He Q . HMGB1 contributes to adriamycin-induced cardiotoxicity via up-regulating autophagy. Toxicol Lett. 2018; 292: 115-122.

6. Pei-Hui Lin. Advances in Autophagy, Tissue Injury, and Homeostasis: Cells 2019; 8: 743.

7. Pattison JS, Robbins J. Protein misfolding and cardiac disease: establishing cause and effect. Autophagy 2008; 4: 821-3.

8. Mei Y, Thompson MD, Cohen RA, Tong X. Autophagy and oxidative stress in cardiovascular diseases. Biochim Biophys Acta 2015; 1852: 243-251.

9. Bodas M, Pehote G, Silverberg D, Gulbins E, Vij N. Autophagy augmentation alleviates cigarette smoke-induced CFTR-dysfunction, ceramide-accumulation and COPD-emphysema pathogenesis. Free Radic Biol Med 2019; 131: 81-97.

10. Li DL , Wang ZV, Ding G, Tan W, Luo X , Criollo A, Xie M, Jiang N, May H, , Schneider JW, Gillette TG, Hill JA. Doxorubicin blocks cardiomyocyte autophagic flux by inhibiting lysosome acidification. Circulation 2016, 133: 1668-1687.

11. Hariharan N, Maejima Y, Nakae J, Paik J, Depinho RA, Sadoshima J. Deacetylation of FoxO by Sirt1 Plays an Essential Role in Mediating StarvationInduced Autophagy in Cardiac Myocytes. Circ Res 2010; 107:1470-82

12. Kopeina GS, Senichkin VV, Zhivotovsky B. Caloric restriction - A promising anti-cancer approach: From molecular mechanisms to clinical trials. Biochim Biophys Acta Rev Cancer 2017; 1867:29-41

13. Malinowski B, Zalewska K, Węsierska A, Sokołowska MM, Socha M, Liczner G, PawlakOsińska K, Wiciński M. Intermittent Fasting in Cardiovascular Disorders-An Overview. Nutrients 2019; 11: 673

14. Mattson MP, Longo VD, Harvie M. Impact of intermittent fasting on health and disease processes. Ageing Res Rev 2017; 39:46-58.

15. Wan R.; Ahmet I.; Brown M.; Cheng A.; Kamimura N.; Talan M.; Mattson M. P. Cardioprotective effect of intermittent fasting is associated with an elevation of adiponectin levels in rats. J Nutr Biochem 2010; 21: 413-7.
16. Ahmet I,Wan R, Mattson MP, Lakatta EG, Talan $\mathrm{M}$. Cardioprotection by intermittent fasting in rats. Circulation 2005; 112: 3115-3121.

17. Varga I, Danisovic L, Kyselovic J, Gazova A, Musil P, Miko M, Polak S.The functional morphology and role of cardiac telocytes in myocardium regeneration. Can. J. Physiol Pharmacol 2016; 94: $1117-1121$

18. Bei, Y, Wang F, Yang C, and Xiao J. Telocytes in regenerative medicine. J Cell Mol Med 2015; 19: 1441-1454.

19. Dos Santos DS, Goldenberg RC. DoxorubicinInduced Cardiotoxicity: From Mechanisms to Development of Efficient Therapy, Cardiotoxicity, Wenyong Tan, IntechOpen, 2018; DOI: 10.5772/ intechopen.79588.

20. Wilson RA, Deasy W, Stathis CG, Hayes A, Cooke MB. Intermittent Fasting with or without Exercise Prevents Weight Gain and Improves Lipids in DietInduced Obese Mice. Nutrients 2018; 10 (3): 346.

21. Zhang YY, Yi M, Huang YP. Oxymatrine Ameliorates Doxorubicin-Induced Cardiotoxicity in Rats. Cell Physiol Biochem 2017; 43: 626-635.

22. El-Akabawy G, El-Kholy W. Neuroprotective effect of ginger in the brain of streprozotocininduced diabetic rats. Ann Anat 2014; 169: 119- 128

23. Frazier JM, Tyson CA. lipid peroxidation In: In vitro toxicity indicators (part B): Methods in toxicology. 1ST ed. Elsevier, 2013. pp. 367-376.

24. Yu W, Sun H, Zha W, Cui W, Xu L, Min Q, Wu J. Apigenin Attenuates Adriamycin-Induced Cardiomyocyte Apoptosis via the PI3K/AKT/ mTOR Pathway. Evid Based Complement Alternat Med 2017; 2017:2590676.

25. Kawaguchi T, Takemura G, Kanamori H, Takeyama T, Watanabe T, Morishita K, Ogino A, Tsujimoto A, Goto K, Maruyama R, Kawasaki M, Mikami A, Fujiwara T, Fujiwara H, Minatoguchi S.. Prior starvation mitigates acute doxorubicin cardiotoxicity through restoration of autophagy in affected cardiomyocytes .Cardiovascular Research 2012; 96: 456-465.

26. Komatsu M, Waguri S, Koike M, Sou YS, Ueno T, Hara T, Mizushima N, Iwata J, Ezaki J, Murata S, Hamazaki J, Nishito Y, Iemura S, Natsume T, Yanagawa T, Uwayama J, Warabi E, Yoshida H, Ishii T, Kobayashi A, Yamamoto M, Yue Z, Uchiyama Y, Kominami E, Tanaka K. Homeostatic levels of p62 control cytoplasmic inclusion body formation in autophagy-deficient mice. Cell 2007; 131:1149-1163. 
27. Suvarna K, Layton C, Bancroft J. The Hematoxylin and eosin, Connective and mesenchymal tissues with their stains, Immunohistochemical techniques and Transmission electron microscopy In: Bancroft's Theory and practice of Histological Techniques, 7th ed, Churchill Livingstone Elsevier, Oxford. 2013. pp. 173-186, 187-214, 381-426and 493-438.

28. Dykstra MJ and Reuss LE. Staining methods for semithins and ultra thins. In: Biological electron microscopy, theory, techniques and troubleshooting. 2nd ed. Kluwer Academic Publishers/Plenum Publishers. 2003. pp.175- 196.

29. Emsley R, Dunn G, White IR. Mediation and moderation of treatment effects in randomised controlled trials of complex interventions. Stat Methods Med Res. 2010; 19: 237-270.

30. DeSantis CE, Lin CC, Mariotto AB, Siegel RL, Stein KD, Kramer JL, Alteri R, Robbins AS, Jemal A. Cancer treatment and survivorship statistics. CA Cancer J Clin 2014; 64: 252-71.

31. Alsuhailbani E, Menon A, Nair C. Protective effect of ayurvedic formulations against doxorubicininduced cardiotoxicity: preliminary studies on Brahma Rasayana and Chyavanaprash. J Can Res Ther 2016; 12:561-564.

32. Yu W, Sun H, Zha W, Cui W, Xu L, Min Q, Wu J. Apigenin Attenuates Adriamycin-Induced Cardiomyocyte Apoptosis via the PI3K/AKT/ mTOR Pathway. Evid Based Complement Alternat Med 2017; 2017:2590676

33. Mitry MA, Edwards JG. Doxorubicin induced heart failure: Phenotype and molecular mechanisms. Int J Cardiol Heart Vasc 2016; 10:17-24.

34. Yassien R I, Elsaid A F. The Possible Protective Role of Melatonin on Doxorubicin Induced Cardiomyopathy of Adult Male Albino Rats. Egyptian Journal of Histology 2017; 40 (1): 25-36

35. Shaker RA, Abboud SH, Assad HC, Hadi N. Enoxaparin attenuates doxorubicin induced cardiotoxicity in rats via interfering with oxidative stress, inflammation and apoptosis. BMC Pharmacol Toxicol 2018; 19: 3.

36. Zhang QL, Yang JJ, Zhang HS. Carvedilol (CAR) combined with carnosic acid (CAA) attenuates doxorubicin-induced cardiotoxicity by suppressing excessive oxidative stress, inflammation, apoptosis and autophagy. Biomedicine \& Pharmacotherapy 2019; 109: 71-83.

37. Lin An, Xiao-wen Hu, Shasha Zhang, Xiaowen $\mathrm{Hu}$, Zongpei Song, Amber Naz, Zhenguo Zi, Jian $\mathrm{Wu}$, Can Li, Yunzeng Zou, Lin He, Hongxin Zhu. UVRAG deficiency exacerbates doxorubicininduced cardiotoxicity. Sci Rep 2017; 7: 43251.
38. Ascensao A, Oliveira PJ, Magalhaes J. Exercise as a beneficial adjunct therapy during doxorubicin treatment-Role of mitochondria in cardioprotection. International Journal of Cardiology 2012; 156: 4-10.

39. Su H, Gorodny N, Gomez LF, Gangadharmath U, Mu F, Chen G, Walsh JC, Szardenings K, Kolb HC, Tamarappoo B. Noninvasive molecular imaging of apoptosis in a mouse model of Anthracyclineinduced Cardiotoxicity PET imaging of apoptosis. CircCardiovasc Imaging 2015; 8: 1-18.

40. Yang DS, Kumar A, Stavrides P, Peterson J, Peterhoff CM, Pawlik M, Levy E, Cataldo AM, Nixon RA. Neuronal apoptosis and autophagy cross talk in aging PS/APP mice, a model of Alzheimer's disease. Am J Pathol 2008; 173: 665-81.

41. Chen T, Deng Z, Zhao R, Shen H, Li W.SYKT Alleviates Doxorubicin-Induced Cardiotoxicity via Modulating ROS-Mediated p53 and MAPK Evid Based Complement Alternat Med 2018; 2018: 2581031.

42. Luu AZ, Chowdhury B, Al-Omran M, Teoh H, Hess DA, Verma S. Role of Endothelium in Doxorubicin-Induced Cardiomyopathy. JACC Basic Transl Sci 2018; 3:861-870.

43. Aird WC. Phenotypic heterogeneity of the endothelium. II: representative vascular beds. Circ Res 2007; 100:174-90.

44. Bartlett JJ, Trivedi PC, Pulinilkunnil T.Autophagic dysregulation in doxorubicin cardiomyopathy, J. Mol. Cell. Cardiol 2017; 104 1-8.

45. Hale AN, Ledbetter DJ, Gawriluk TR, Rucker EB Autophagy: regulation and role in development. Autophagy 2013; 9:951-972.

46. Bravo-San Pedro JM, Kroemer G, Galluzzi L. Autophagy and mitophagy in cardiovascular disease. Circ Res 2017; 120: 1812-1824.

47. Kurz T, Terman A, Gustafsson B, Brunk UT. Lysosomes and oxidative stress in aging and apoptosis. Biochim Biophys Acta 2008; 1780: 1291-1303.

48. Kim KH, Lee MS. Autophagy-a key player in cellular and body metabolism. Nat Rev Endocrinol 2014; 10: 322-37.

49. Ylä-Anttila P, Vihinen H, Jokitalo E, Eskelinen EL.Methods in Enzymology, Volume p.144163452. Monitoring Autophagy by Electron Microscopy in Mammalian Cells. Methods Enzymol 2009; 452:143-64.

50. Koleini N, Kardami E. Autophagy and mitophagy in the context of doxorubicin-induced cardiotoxicity. Oncotarget 2017; 8:46663-80. 
51. Shi J, Surma M, Wei L. Disruption of ROCK1 gene restores autophagic flux and mitigates doxorubicin-induced cardiotoxicity. Oncotarget 2018; 9: 12995-13008.

52. Xiao B, Hong L, Cai X, Mei S, Zhang P, Shao L.The true colors of autophagy in doxorubicin induced cardiotoxicity Oncol Lett 2019; 18: $2165-2172$.

53. Driver C, Bamitale KDS, Kazi A, Olla M, Nyane NA, Owira PMO. The Cardioprotective Effect of Metformin .J Cardiovasc Pharmacol 2018; 72: 121-127.

54. Thomas CM, Yong QC, Rosa RM, Seqqat R, Gopal $\mathrm{S}$, Casarini DE, Jones WK, Gupta S, Baker KM, Kumar R. Cardiac-specific suppression of NF- $\kappa B$ signaling prevents diabetic cardiomyopathy via inhibition of the renin-angiotensin system, Am. J. Physiol. Heart Circ Physiol 2014; 307: 1036-1045.

55. Murakawa T, Nakayama H, Nishida K, Akira S, Yamamoto A, Komuro I, Otsu K. Mitochondrial DNA that escapes from autophagy causes inflammation and heart failure. Nature 2012; 485:251-255.

56. Cappetta D, De Angelis A, Sapio L, Prezioso L, Illiano M, Quaini F, Rossi F, Berrino L, Naviglio S, Urbanek K. Oxidative Stress and Cellular Response to Doxorubicin: A Common Factor in the Complex Milieu of Anthracycline Cardiotoxicity. Oxid Med Cell Longev 2017; 2017:1521020.

57. Manole CG, Gherghiceanu M, Simionescu O. Telocyte dynamics in psoriasis. J Cell Mol Med 2015; 19:1504-1519.

58. Kostin S. Cardiac telocytes in normal and diseased hearts. Semin Cell Dev Biol 2016; 55:22-30.

59. Li S, Shen X, He S. Expression of toll-like receptors and their regulatory roles in murine cardiac telocytes. J Cell Mol Med. 2019; 23: $5360-5368$.

60. Abdel-Maksoud FM, Abd-Elhafeez HH, Soliman SA. Morphological changes of telocytes in camel efferent ductules in response to seasonal variations during the reproductive cycle. Sci Rep 2019; 9:4507.

61. De Groot S, Pijl H, van der Hoeven JJM, Kroep JR. Effects of short-term fasting on cancer treatment. J Exp Clin Cancer Res 2019; 38: 209.

62. Lee C, Raffaghello L, Brandhorst S, Safdie FM, Bianchi G, Martin-Montalvo A, Pistoia V, Wei M, Hwang S, Merlino A, Emionite L, de Cabo $\mathrm{R}$, Longo VD. Fasting cycles retard growth of tumors and sensitize a range of cancer cell types to chemotherapy. Sci Transl Med 2012; 4:124ra27.
63. Johnstone A. Fasting for weight loss. An effective strategy or latest dieting trend? Int J Obes 2014; 39:727-733.

64. Withers SS, Kass PH, Rodriguez CO Jr, Skorupski KA, O'Brien D, Guerrero TA, Sein KD, Rebhun $\mathrm{RB}$. Fasting reduce the incidence of delayed type vomiting associated with doxorubicin treatment in dogs with lymphoma. Translational oncology 2014; $7: 377-383$.

65. Michalsen A, Li C. Fasting therapy for treating and preventing disease-current state of evidence. Forsch Komplementmed 2013; 20: 444-53.

66. Katare RG, Kakinuma Y, Arikawa M, Yamasaki F, Sato T. Chronic intermittent fasting improves the survival following large myocardial ischemia by activation of BDNF/VEGF/PI3K signaling pathway. J Mol Cell Cardiol 2009; 46: 405-412.

67. Saito T, Sadoshima J. Molecular mechanisms of mitochondrial autophagy/mitophagy in the heart. Circulation Research 2015; 116: 1477-1490.

68. Gherghiceanu M, Popescu LM. Cardiac telocytes - their junctions and functional implications. Cell Tissue Res 2012; 348:265-279.47.

69. Fertig ET, Gherghiceanu M, Popescu LM. Extracellular vesicles release by cardiac telocytes: electron microscopy and electron tomography. J Cell Mol Med 2014; 18:1938-1943.

70. Smythies J, Edelstein L. Telocytes, exosomes, gap junctions and the cytoskeleton: the makings of a primitive nervous system? Frontiers in cellular neuroscience 2014; 7: 278.

71. Zheng Y, Bai C. \& Wang, X. Telocyte morphologies and potential roles in diseases. Journal of cellular physiology 2012; 227: 2311-2317.

72. Marini M, Mencucci R, Rosa I, et al. Telocytes in normal and keratoconic human cornea: an immunohistochemical and transmission electron microscopy study. J Cell Mol Med 2017; 21:3602-3611.

73. Xiao J, Chen P, Qu Y, Yu P, Yao J , Wang H, Fu S, Bei Y, Chen Y, Che L, Xu J .Telocytes in exercise-induced cardiac growth. J Cell Mol Med 2016; 20:973-979.

74. Popescu LM, Faussone-Pellegrini MS. TELOCYTES - a case of serendipity: the winding way from Interstitial Cells of Cajal (ICC), via Interstitial Cajal-Like Cells (ICLC) to TELOCYTES. J Cell Mol Med 2010; 14: 729-740.

75. Manole CG, Cismaşiu V, Gherghiceanu M, Popescu LM. Experimental acute myocardial infarction: telocytes involvement in neo-angiogenesis. J Cell Mol Med 2011; 15:2284-2296. 
76. De Angelis A, Piegari E, Cappetta D, Marino L, Filippelli A,Berrino L, Ferreira-Martins J, Zheng H, Hosoda T, Rota M, Urbanek K, Kajstura J, Leri A, Rossi F, Anversa P . Anthracycline cardiomyopathy is mediated by depletion of the cardiac stem cell pool and is rescued by restoration of progenitor cell function. Circulation 2010; 121:276-292.

77. Mihaylova MM, Cheng CW, Cao AQ, Tripathi $\mathrm{S}$, Mana MD, Bauer-Rowe KE, Abu-Remaileh M, Clavain L, Erdemir A, Lewis CA, Freinkman E, Dickey AS, La Spada AR, Huang Y, Bell GW, Deshpande V, Carmeliet P, Katajisto P, Sabatini DM, Yilmaz OH.. Fasting Activates Fatty Acid Oxidation to Enhance Intestinal Stem Cell Function during Homeostasis and Aging. Cell Stem Cell 2018; 22: 769-778.

78. Quaife-Ryan GA, Sim CB, Porrello ER, Hudson JE. Resetting the epigenome for heart regeneration. Semin Cell Dev Biol 2016; 58: 2-13.
79. Beltrami AP, Barlucchi L, Torella D, Baker M, Limana F, Chimenti S, Kasahara H, Rota M, Musso E, Urbanek K, Leri A, Kajstura J, NadalGinard B, Anversa P. Adult cardiac stem cells are multipotent and support myocardial regeneration. Cell 2003; 114:763-76.

80. Messina E, De Angelis L, Frati G, Morrone S, Chimenti S, Fiordaliso F, Salio M, Battaglia M, Latronico MV, Coletta M, Vivarelli E, Frati L, Cossu G, Giacomello A.Isolation and expansion of adult cardiac stem cells from human and murine heart. Circ Res 2004; 95:911-21.

81. Takeda N, Manabe i. Cellular interplay between cardiomyocytes and non myocytes in cardiac remodeling. Int J Inflam 2011; 2011:535241.

82. Balakumar P, Singh AP, Ganti SS, Krishan P, Ramasamy S, Singh M. Resident cardiac mast cells: are they the major culprit in the pathogenesis of cardiac hypertrophy?. BCPT 2008; 102: 5-9. 


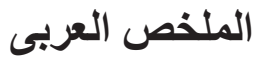

\section{الصيام المتقطع يضعف موت الخلايا المبرمج ويعدل الالتهام الذاتي ويحافظ على الخلايا ذات الامتدادات في تسمم القلب المُحدث بعقار الدوكسوروبيسين في الجرذان البيضاء: دراسة هستولوجية}

\section{إيمان عباس فرج ومروة محمد صبرى}

\section{قسم علم الأنسجة ـ كلية الطب - جامعة القاهرة}

الخلقية: يستخدم عقار دوكسوروبيسين على نطاق و اسع كمضاد فعال للسرطان، ولكن يحد من استخدامه آثاره شديدة

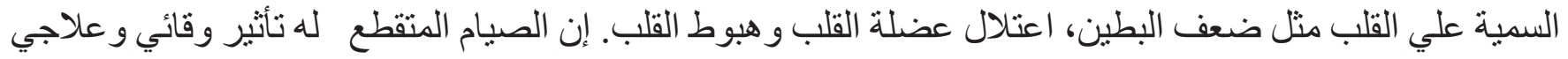

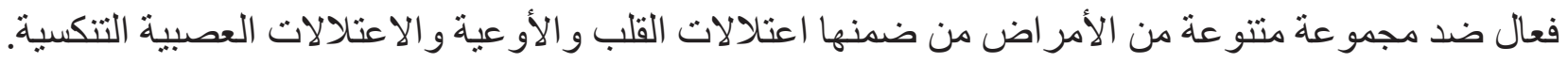
الهدف من العمل: فحص تأثثير ات دوكسورو بيسين على التركيب النسيجي لعضلة القلب وتقييم التأثير ات الوقائية المحتملة للصيام المتقطع علي القلب من هذه التغيير ات. المو اد وطرق البحث: تم تقسيم ثمانية وأربعين من ذكور الجرذان البيضاء البالغة إلى أربع مجمو عات متساوية: الضابطة

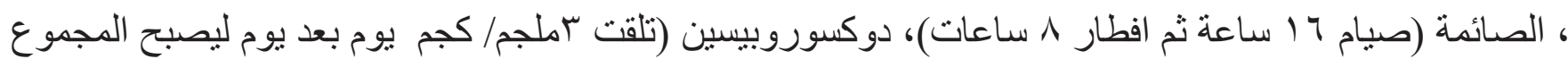

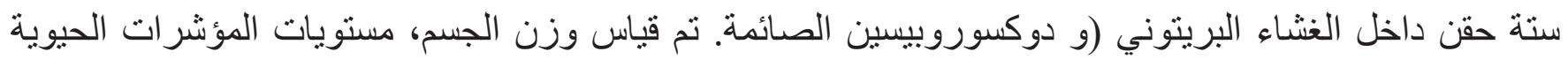
للقلب، مالونديالدهيد ودلالات الالتهام الذاتي (II3LC و 62p). تم معالجة البطين الأيسر لإعداد بلوكات البار افين

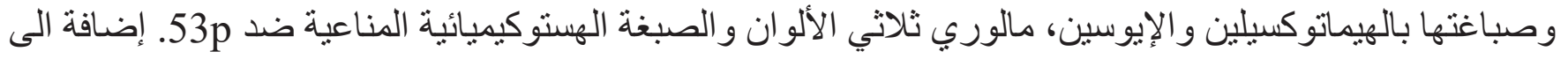
ذللك تم إعداد بلوكات الر اتين لفحص القطاعات النصف رقيقة والرقيقة. تم إجر اء القياسات المترية الثكلية والإحصائية. النتائج: أظهرت مجموعة دوكسوروبيسين زيادة ملحوظة في المؤشرات الحيوية للقلب، مستويات مالونديالدهيد،

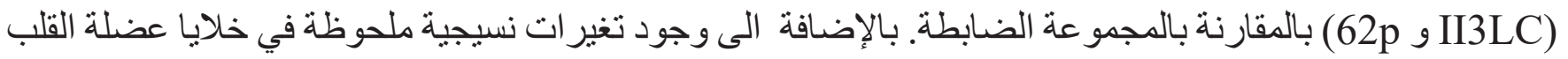

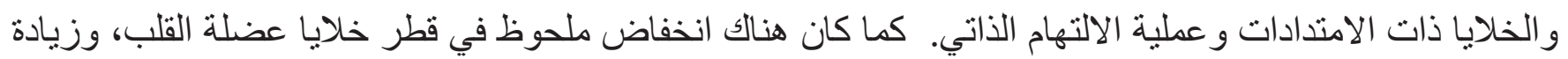
ملحوظة في عدد الخلايا الإيجابية للصبغة الهستوكيميائية المناعية ضد $53 p$ وفي منوسط النسبة المئوية لمساحة الياف

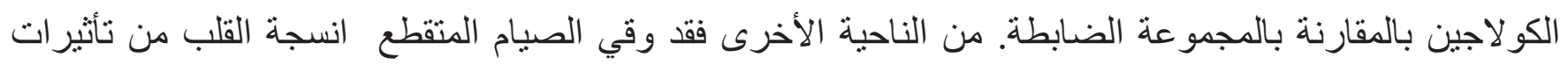

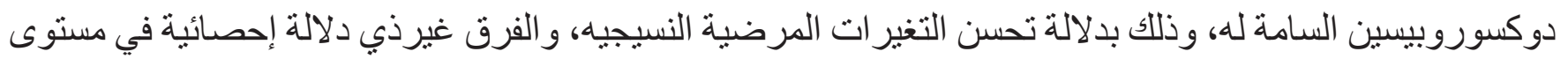

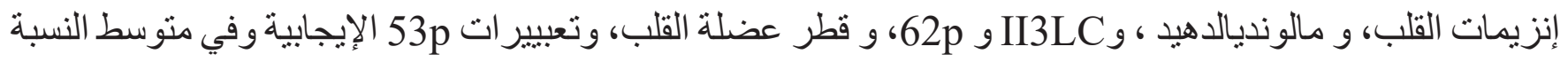

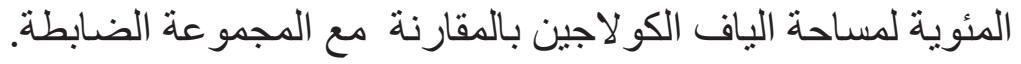
الاستنتاج: أدي تتاول دوكسوروبيسين إلى تأثير ات ضارة على عضلة القلب. الصيام المتقطع له تأثثر ات وقائية علي

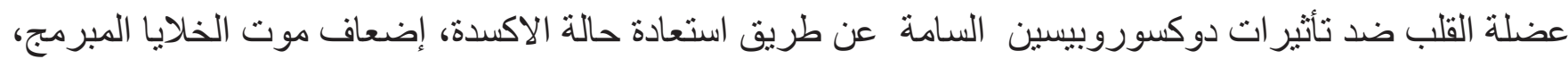
تتظيم عملية الالتهام الذاتي و الحفاظ على الخلايا ذات الامتدادات. 